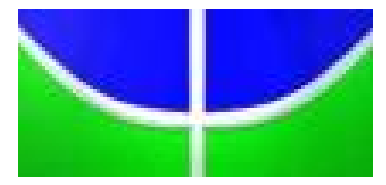

UNIVERSIDADE DE BRASÍLIA

Centro de Excelência em Turismo

Pós-graduação Lato Sensu

Curso de Especialização em Gestão de Negócios em Turismo

\title{
TURISMO E EVENTOS PARA A TERCEIRA IDADE EM BRASÍLIA
}

Ana Carolina Meireles Ramos 
UNIVERSIDADE DE BRASÍLIA

Centro de Excelência em Turismo

Pós-graduação Lato Sensu

Curso de Especialização em Gestão de Negócios em Turismo

\title{
TURISMO E EVENTOS PARA A TERCEIRA IDADE EM BRASÍLIA
}

\author{
ANA CAROLINA MEIRELES RAMOS \\ Professora Orientadora: Mestre Shirley Pontes \\ Monografia apresentada ao Centro de \\ Excelência em Turismo - CET, da \\ Universidade de Brasília - UnB, como \\ requisito parcial à obtenção do grau de \\ especialista em Gestão de Negócios em \\ Turismo.
}


Ramos, Ana Carolina Meireles.

Turismo e eventos para a Terceira Idade em Brasília/ Ramos, Ana Carolina Meireles - Brasília, 2007. $x, 80 \mathrm{f}$. : il.

Monografia (especialização) - Universidade de Brasília, Centro de Excelência em Turismo, 2007.

Orientadora: Mestre Shirley Pontes

1. Turismo 2. Terceira Idade 3. Marketing 
UNIVERSIDADE DE BRASÍLIA

Centro de Excelência em Turismo

Pós-graduação Lato Sensu

Curso de Especialização em Gestão de Negócios em Turismo

TURISMO E EVENTOS PARA A TERCEIRA IDADE EM BRASÍLIA

ANA CAROLINA MEIRELES RAMOS

APROVADO POR:

Professora Orientadora: Shirley Pontes, MSc

Professor: Domingos Spezia, MSc

Professor: Gilson Zehetmeyer Borda, Dr.

Brasília, 11 de junho de 2007. 


\section{DEDICATÓRIA}

Dedico esta monografia aos meus pais Brasilino e lara. Agradeço-os pela minha existência, e também pela amizade, pelo carinho, pela força, pelo incentivo, por acreditarem em $\mathrm{mim}$ e me apoiarem em todos os momentos do meu curso e da minha vida. Eles são minhas referências de amor, dedicação, apoio, respeito e sucesso.

Amo muito vocês. Muito obrigada por tudo. 


\section{AGRADECIMENTOS}

Agradeço primeiramente a Deus, que me deu a força necessária para superar todos os obstáculos do meu caminho e por ter me concedido tantas graças.

Aos meus irmãos: Renata, Pedro Paulo e Larissa, pela ajuda, compreensão e que me ouviram tantas vezes, auxiliando-me na realização deste trabalho, e em todos os momentos na trajetória do meu curso. Ao meu sobrinho Lucca e minha vó Tuna, por serem os meus anjinhos da guarda e exemplo de coragem e fé!

Ao meu namorado Jair, pela paciência, companheirismo, amor e força.

À minha família e aos meus amigos pela amizade, apoio e companheirismo.

À professora Shirley Pontes, orientadora desta monografia, por sua amizade, profissionalismo, carinho, atenção e paciência.

Aos funcionários e colaboradores do Centro de Excelência e Turismo da UnB.

Enfim, a todos os mestres pelos ensinamentos e incentivos na minha vida e profissionalmente. 
Sofremos não porque envelhecemos, mas porque o futuro está sendo confiscado de nós, impedindo assim que mil aventuras nos aconteçam, todas aquelas com as quais sonhamos e nunca chegamos a experimentar.

$[\ldots]$

A cada dia que vivo, mais me convenço de que o desperdício da vida está no amor que não damos, nas forças que não usamos, na prudência egoísta que nada arriscamos, e que, esquivando-se do sofrimento, perdemos também a felicidade.

A dor é inevitável. O sofrimento é opcional.

Carlos Drummond de Andrade 


\section{RESUMO}

O envelhecimento populacional que ocorre no Brasil oportuniza o desenvolvimento do turismo para a Terceira Idade, permitindo compreender melhor a oferta de produtos e serviços adequados oferecidos a esse segmento. Assim, o presente trabalho levantou como questão de estudo a análise de mercado do perfil desse tipo de consumidor em Brasília: seus hábitos de consumo, lazer e entretenimento. A metodologia deste trabalho foi elaborada em duas etapas. Na primeira, realizou-se um levantamento bibliográfico em livros, revistas, sites da internet, seguido de uma investigação documental em busca de dados secundários em órgãos e associações, para a elaboração do referencial teórico. Em seguida, fez-se a pesquisa de campo, que teve como instrumento um questionário aplicado ao público da Terceira Idade em geral (pesquisa quantitativa), com 93 respondentes, e aos gerentes do Núcleo de Estudo e Pesquisa da Terceira Idade (NEPTI) e do Serviço Social do Comércio (SESC), que promovem eventos para esta população (pesquisa qualitativa - semiestruturada). Os dados foram coletados em Brasília, tabulados na planilha eletrônica MS Excel, e analisados segundo estatística descritiva. A conclusão foi que a cidade não se encontra totalmente adaptada para atender ao lazer e ao entretenimento desse segmento populacional. Assim, pretende-se que os resultados deste trabalho sirvam como fonte de informação aos gestores da área em questão, fornecendo-lhes

subsídios para ajuda-los no aperfeiçoamento dos serviços para esse importante nicho de mercado.

Palavras-chaves: Turismo, Terceira Idade, Marketing 


\begin{abstract}
The population aging that occurs in Brazil opportunism the development of the tourism for the Third Age, allowing to understand better offers of products and adequate services offered this segment. Thus, the present work raised as study question the analysis of market of the profile of this type of consumer in Brasilia: its habits of consumption, leisure and entertainment. The methodology of this work was elaborated in two stages. In the first one, one became fulfilled a bibliographical survey in books, magazines, sites of the Internet, followed of a documentary inquiry in search of secondary data in agencies and associations, for the elaboration of the theoretical referencial. After that, it became research of field, that had as instrument a questionnaire applied to the public of the Third Age in general (quantitative research), with 93 respondents, and to the controlling of the Nucleus of Study and Research of Third Age (NEPTI) and of the Social Service of Commerce (SESC), that they promote events for this population (qualitative research - half-structuralized). The data had been collected in Brasilia, tabulated in electronic spread sheet MS Excel, and analyzed according to descriptive statistics. The conclusion was that the city does not meet total suitable to take care of to the leisure and the entertainment of this population segment. Thus, one intends that the results of this work serve as source of information to the managers of the area in question, supplying subsidies helps them to them in the perfectioning of the services for this important niche of market.
\end{abstract}

Keywords: Tourism, Third age, Marketing 


\section{LISTA DE QUADROS}

Quadro 1 - Quantidade e percentual de pessoas residentes com 60 anos ou mais

Quadro 2 - Esperança de vida ao nascer, por sexo, taxa de fecundidade e taxa de mortalidade.

Quadro 3 - Formas de segmentar o mercado.

Quadro 4 - Comparação entre bens e produtos gerais e produto turístico. 


\section{LISTA DE GRÁFICOS}

Gráfico 1 - Gênero $\quad 29$

Gráfico 2 - Tempo que residem em Brasília $\quad 30$

Gráfico 3 - Estado civil 31

Gráfico 4 - Faixa etária $\quad 31$

Gráfico 5 - Status profissional 32

Gráfico 6 - Escolaridade $\quad 32$

Gráfico 7- Rendimento mensal 33

Gráfico 8 - Residência $\quad 34$

Gráfico 9 - Moradia $\quad 34$

Gráfico 10 - Atividade que mais se identificam 35

Gráfico 11- Principais motivos para saírem de casa 35

Gráfico 12 - Lugares que costumam sair a lazer 36

Gráfico 13 - Tipos de programação que gostariam que existisse para melhorar/ 36 aumentar, as opções de lazer e entretenimento em Brasília. 


\section{SUMÁRIO}

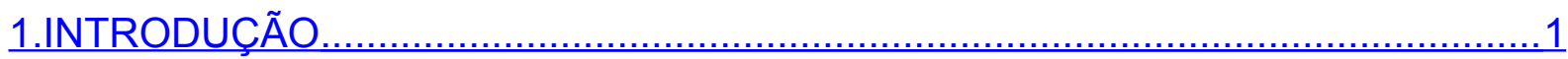

2.TURISMO E EVENTOS

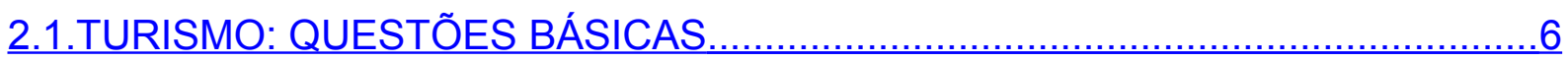

2.2.TURISMO DE EVENTOS E A TERCEIRA IDADE...............................................

2.3.TERCEIRA IDADE .............................................................................11

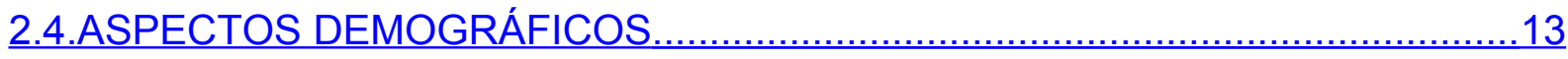

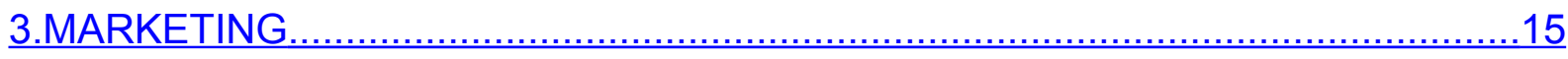

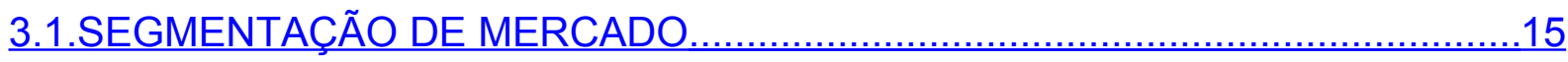

3.2.COMPORTAMENTO DO CONSUMIDOR DA TERCEIRA IDADE .....................19

3.3.BRASÍLIA: ADEQUAÇÃO AO LAZER DA TERCEIRA IDADE.............................21

3.3.1.Infra-estrutura da cidade ....................................................................22

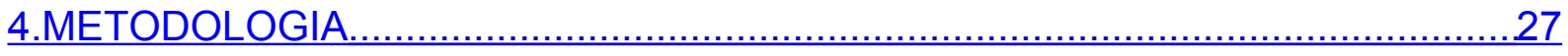

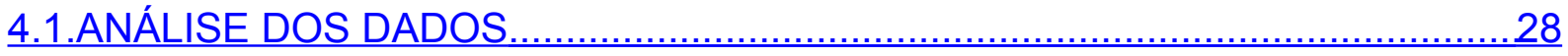

4.1.1.Perfil do respondente ...............................................................................29

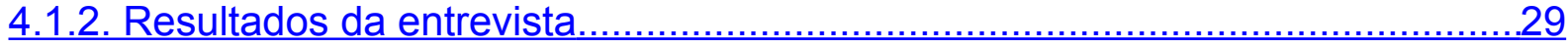

4.1.3. Resultado da entrevista com o SESC .........................................................37

4.1.4. Resultado da entrevista com o NEPTI ........................................................39

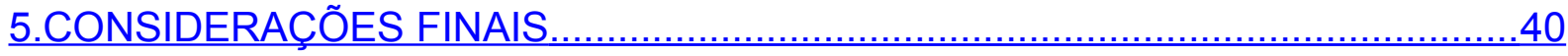

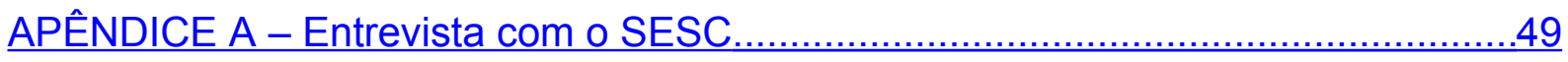

APÊNDICE B - Entrevista com o NEPTI.............................................................51

APÊNDICE C - Questionário - quantitativo...............................................................53

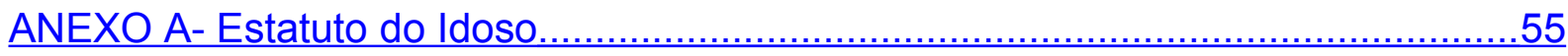




\section{INTRODUÇÃO}

Análises demográficas têm apontado a tendência de envelhecimento da população mundial, e as projeções para o Brasil - sempre considerado um país de jovens - indicam que, em 2050, o percentual de pessoas com sessenta anos ou mais atingirá $23 \%$ da população total, representando um significativo acréscimo em relação aos $9 \%$ registrados em 1999. (United Nations, 2000).

Segundo Presser $(2005,17)$, o Estatuto do Idoso é destinado a regular os direitos das pessoas com idade igual ou superior a 60 anos, e provê instruções de como operacionalizar a garantia dos direitos assegurados por políticas publicas e mecanismos processuais, como citado nos artigos a seguir:

Art. 1ํ É instituído o Estatuto do Idoso, destinado a regular os direitos assegurados às pessoas com idade igual ou superior a 60 (sessenta) anos.

Art. $2^{\circ} \mathrm{O}$ idoso goza de todos os direitos fundamentais inerentes à pessoa humana, sem prejuízo da proteção integral de que trata esta Lei, assegurando-se-lhe, por lei ou por outros meios, todas as oportunidades e facilidades, para preservação de sua saúde física e mental e seu aperfeiçoamento moral, intelectual, espiritual e social, em condições de liberdade e dignidade.

A mudança na estrutura demográfica indica, emergencialmente, a necessidade de novas prioridades e novas exigências nos diferentes níveis da organização social, gerando impactos nas esferas política, econômica e cultural.

É nesse contexto que se inclui o turismo para a Terceira Idade, pois, além de oferecer opções de diversão e conhecimento, propicia interações sociais e a conquista de novas amizades, minimizando a solidão, e melhorando a qualidade de vida dessas pessoas que, de alguma forma, já deram sua contribuição à família e à sociedade.

O expressivo aumento do número de idosos na população geral é um dado relevante, e que, certamente, influenciará as políticas do setor e a comercialização de produtos. Assim, é fundamental que tal projeção seja absorvida pelos gestores turísticos - públicos e privados - e não seja ignorada pelos pesquisadores da área. 
O segmento da Terceira Idade assume relevância para o mercado de produtos e serviços turísticos, pois:

- os especialistas estão alertando cada vez mais para a necessidade de convívio social, de novas aprendizagens, e de lazer para as pessoas dessa faixa etária;

- praticamente desobrigadas de compromissos profissionais e familiares, são pessoas que dispõem de mais tempo livre para a realização daquilo que não tiveram tempo de fazer quando mais jovens, para aproveitar a vida e realizar seus sonhos;

- a tecnologia tem trazido facilidades para a vida das pessoas de Terceira Idade, com a evolução dos meios de transporte por exemplo, possibilitando que a viagem seja hoje uma “... atividade tão confortável que também eles podem se arriscar, o que antigamente teria sido uma aventura impossível." (Baldessin, 1999, p. 493).

Em concomitância com esses fatores que estimulam o crescimento do turismo para a Terceira Idade, aparecem outros que os dificultam, e que requerem cuidados especiais para que o retorno financeiro sobre este segmento seja satisfatório. Dentre eles estão:

- segundo Ferrari (2005), o despreparo para o lazer, decorrente do desconhecimento de seu significado, de idéias preconceituosas originadas da confusão entre este e o ócio, e da aceitação da capacidade produtiva como centro da vida do indivíduo;

- o estereótipo do processo de envelhecimento, que faz crenças e preconceitos exercerem grandes efeitos negativos, tanto na forma de a sociedade analisar as pessoas de Terceira Idade, quanto na forma de como estas mesmas se consideram, manifestando-se na dificuldade em assimilarem-se às mudanças ocorridas com a idade, e em reconhecer o processo como natural;

Então, não se pode deixar de ressaltar as considerações formuladas na Carta de Recife sobre Turismo para a Terceira Idade, adotadas por aclamação no encerramento da International Conference on Senior Tourism. (WTO, 1997): 
- o turismo para a Terceira Idade deve ser considerado como parte integrante dos grandes movimentos turísticos, e não como um grupo segregado, já que compartilha as mesmas redes e estabelecimentos que os outros usuários e consumidores;

•em razão de sua natureza tão pelicular, requer a adoção de estratégias de marketing criativas e adequadas, desenvolvendo produtos turísticos capazes de satisfazer as necessidades e características de seus participantes;

•a importância do turismo para a Terceira Idade está no fato de que, mais que um mercado especial, o mesmo pode ser considerado como uma prefiguração do futuro turismo de massas.

A tendência de crescimento da população idosa ampliará as possibilidades de negócios para as agências de viagens, para os transportadores turísticos, para a rede hoteleira e de alimentação, enfim, para as diferentes áreas da economia atingidas pelo turismo. Portanto, para o desenvolvimento desse nicho de mercado, devem ser respeitadas e conhecidas as especificidades deste tipo de cliente, o que propiciará as condições favoráveis para que o tempo dos idosos seja preenchido em atividades que os agradem, e que possam, nelas, utilizar suas aptidões, contribuindo para a melhoria de sua saúde mental e física.

O crescimento da população idosa em Brasília é reflexo do envelhecimento dos candangos. Hoje, a necessidade de estar perto de filhos e netos é uma das principais razões para que permaneçam na cidade, sem contar o fato de a capital federal ser considerada por muitos uma cidade calma e com boa qualidade de vida, no que diz respeito, principalmente, à alimentação, a locais para lazer, saúde, escolaridade e outros.

Brasília possui inúmeras áreas verdes, parques e locais para distração, e, quando se chega a uma certa idade, não é apropriado ficar dentro de casa sem nenhuma ocupação. O importante é fazer com que a vida seja diferente, e que cada minuto seja vivido com intensidade.

Qualidade de vida e valorização da Terceira Idade fazem de Brasília o lugar ideal para envelhecer e invertem o sonho de quem pensava em se aposentar e voltar para a cidade de origem. Entre os moradores acima de 60 anos, $67 \%$ têm renda própria. (Érica Monteiro e Valéria Feitosa, da equipe do Correio Brasiliense (14/07/2002), http://www.correioweb.com.br, acesso em 27/10/2006.)

A qualidade de vida para os integrantes da Terceira Idade, em uma cidade como Brasília, envolve vários aspectos, principalmente o prazer de se ter um corpo 
saudável, a aceitação dos seus limites, de interagir com a sociedade, e de satisfazer seus desejos na medida do possível. Para eles, envelhecer bem significa satisfação com a vida atual, e, ao mesmo tempo, ter expectativas positivas em relação ao futuro, sendo lógico que, para se pensar no que há de vir, deve-se prestar atenção, também, em cuidar-se da saúde física e psicológica, na produtividade, no status social, na renda, entre outras coisas.

Esta pesquisa é importante porque a cada dia que passa os eventos estão crescendo, e Brasília está se abrindo para vários deles, como os turísticos, científicos e promocionais, embora os idosos ainda fiquem à margem, não contando com a atenção necessária para que se desenvolvam atividades específicas direcionadas a esse público alvo. Portanto, a pergunta que norteou esta monografia foi: Qual é o perfil do consumidor da Terceira Idade em Brasília, e qual a sua preferência em termos de lazer e entretenimento?

Portanto, o objetivo desta pesquisa é o de analisar o mercado e o hábito de lazer e entretenimento voltados para o segmento da Terceira Idade em Brasília. Para completá-la, surgiram alguns objetivos específicos, tais como:

-Identificar o perfil do consumidor da Terceira Idade em Brasília, e quais os seus hábitos de consumo de lazer e de entretenimento;

- Fazer um levantamento das necessidades e do que gostariam que fosse oferecido, em Brasília, ao grupo estudado, com relação a eventos e lazer.

As metodologias utilizadas foram a pesquisa bibliográfica a partir de materiais já publicados, como livros, artigos de periódicos, internet, entre outros, e a pesquisa documental, buscando-se dados secundários em órgãos e associações. As formas de abordagem desta pesquisa foram a qualitativa e a quantitativa, de formas direta e específica, abordando-se, em geral, os interesses investigados, sendo somente quantitativa com o público da Terceira Idade.

A análise foi descritiva porque os dados foram coletados por meio de um questionário aplicado no período de 03 a 23 de março, como forma de levantamento para tornar a pesquisa mais completa, e foi qualitativa porque aplicou-se um questionário semi-estruturado junto aos gestores dos órgãos e associações que atendem à Terceira Idade - no caso, o Serviço Social do Comércio (SESC) e o Núcleo e Pesquisa da Terceira Idade (NEPTI) -, e locais de lazer e entretenimento 
mais freqüentados por este público, como, por exemplo, o Clube do Choro, o Parque da Cidade, entre outros. Os dados foram tabulados na planilha eletrônica MS Excel, e analisados segundo a estatística descritiva.

A estrutura deste trabalho é composta por cinco capítulos. Uma apresentação dos aspectos considerados relevantes é feita inicialmente para a compreensão da temática em questão, e utilizada para nortear a pesquisa. No segundo capítulo, são expostas questões sobre turismo de eventos e a Terceira Idade. O terceiro apresenta a relação entre marketing, segmentação de mercado, comportamento do consumidor e a estrutura para a Terceira Idade em Brasília. No quarto capítulo, são comentados os caminhos percorridos durante a realização desta pesquisa, e, por fim, consolida-se o estudo com a apresentação e a análise de resultados das relações entre turismo, eventos, lazer, entretenimento e a Terceira Idade na Capital Federal. 


\section{TURISMO E EVENTOS}

Este capítulo tem por finalidade uma primeira aproximação sobre o tema da pesquisa, apresentando subsídios resultantes da revisão da literatura que permitam contextualizar o turismo e os eventos para a Terceira Idade, e compreender seus conceitos iniciais.

\subsection{TURISMO: QUESTÕES BÁSICAS}

O conceito de turismo é amplo, complexo e inclui as áreas econômica, social e ecológica. Por isso, existem várias definições para o turismo. Segundo Beni (1998, p. 21), "O turismo pode identificar-se em três tendências para sua definição: a econômica, a social e a holística". Neste sentido, vale ressaltar os aspectos conceituais e técnicos que a sua definição possui.

Acerenza (2002) analisa o aspecto conceitual do turismo, enfocando-o sob o ponto de vista das diferentes disciplinas, das diversas correntes de pensamento, do seu significado para a sociedade, e também da sua relação com o tempo livre e com a qualidade de vida. Quanto ao aspecto técnico, o autor refere-se a várias definições de turismo, cada qual apropriada a um propósito diferente, podendo ser uma definição específica para fins estatísticos, outra para fins comerciais, econômicos, e outra para fins jurídicos. O conceito de turismo, como podemos ver, é multifacetado, uma vez que aquelas definições correspondem às necessidades próprias do campo em que são estudados.

O turismo pode ser considerado como uma atividade sócio-econômicocultural que vem destacando-se internacionalmente, tanto nos países denominados desenvolvidos, quanto nos países em desenvolvimento. Assim, na opinião de De La Torre (1997, p.19), 
O turismo é um fenômeno social que consiste no deslocamento voluntário e temporário de indivíduos ou grupo de pessoas que, fundamentalmente por motivos de recreação, descanso, cultural ou saúde, saem do seu local de residência habitual para outro, no qual não exercem nenhuma atividade lucrativa nem remunerada, gerando múltiplas inter-relações de importância social, econômica e cultural.

Andrade (2000) utilizou uma conceituação técnica e comercial do termo, que correspondente ao conjunto de serviços que têm por objetivo o planejamento, a promoção e a execução de viagens, assim como a recepção, hospedagem e atendimento aos indivíduos e aos grupos fora de suas residências habituais.

Segundo o Instituto Brasileiro de Turismo - EMBRATUR (2000, p. 57), em uma visão completamente econômica, turismo é "a atividade econômica representada pelo conjunto de transações turísticas (compra e venda de bens e serviços). Como se pode ver, este conceito mostra apenas a parte relacionada às transações entre oferta e a demanda que formam esse mercado.

Já a Organização Mundial do Turismo - OMT (1995) conceitua turismo como o "deslocamento voluntário e temporário do homem fora sua residência habitual, por uma razão diferente que a de exercer uma atividade remunerada". Ela destaca principalmente o deslocamento de indivíduos - que deve ser "voluntário e temporário" -, pois a pessoa necessita de motivação para se deslocar, e deve ter um tempo pré-estabelecido superior a 24 horas, incluindo o pernoite. Enfatiza que o turista não deve exercer nenhuma atividade remunerada no centro receptor, pois fugirá do conceito acima. Se ele viajar a negócios, irá retirar divisas do local e não deixá-las. Entretanto, existe o turismo de negócios, em que o indivíduo vai a trabalho e, mesmo assim, efetua gastos significativos no local visitado - sendo ele, sob este aspecto, também considerado turista.

Os conceitos acima mostram como o turismo é complexo, pois lida com motivações, viagens, diferentes culturas e ainda vários segmentos dessa área, e é entendido como um fenômeno múltiplo, que envolve o deslocamento provisório de pessoas, entre diferentes territórios por motivos diversos, gerando renda e outras transformações.

Dentre as muitas finalidades do turismo, pode-se apontar a oferta de lazer aos viajantes e a possibilidade de trocas culturais e afetivas entre visitante e população local, proporcionando uma ampla interação entre turistas, profissionais da 
área e moradores. Esta atividade, se bem planejada, pode favorecer o crescimento de qualquer localidade receptora, com distribuição de benefícios entre os vários agentes e os residentes.

\subsection{TURISMO DE EVENTOS E A TERCEIRA IDADE}

A Terceira Idade ainda é um segmento pouco explorado pelo turismo. A literatura sobre o tema é escassa, sobretudo acadêmica, e a oferta turística se resume a poucas iniciativas isoladas.

Os profissionais da área provavelmente não reconheçam-na como um público consumidor atraente em razão de ainda associarem a velhice a uma fase de debilidade física e de dependência financeira. Entretanto, esse é um segmento com grande potencial para usufruir o turismo, eventos, e outros.

Há diversas definições para o turismo de eventos, e, inclusive, existem estudiosos que dão maior ou menor importância a esse fenômeno. No entanto, torna-se cada vez mais indiscutível a crescente importância dos mais variados eventos para as atividades econômicas do turismo.

Segundo Andrade (2002, p. 15), turismo de eventos é o conjunto de atividades exercidas por pessoas que viajam a fim de participar dos diversos tipos de eventos que visam ao estudo de alternativas, de dimensionamento ou de interesses de determinada categoria profissional, associação, clube, crença religiosa, corrente científica, técnicos e religiosos para atingir metas profissionais e culturais, técnicos e operacionais, de aperfeiçoamento setorial ou de atualização.

Toda pessoa que participa de um evento tem a oportunidade de praticar turismo. Portanto, o primeiro, em si, gera o segundo, pois, sendo também um atrativo, cria fluxo turístico. Além disso, não havendo oportunidade de conhecer bem a cidade naquele momento, o participante que descobriu o destino turístico pode voltar em outra ocasião, acompanhado da família ou dos amigos. Há também a promoção da imagem positiva do lugar, que pode gerar a vinda de outros visitantes. 
Pode-se dizer, então, que o turismo de eventos alavanca o turismo de lazer, e que o mercado de eventos está profundamente ligado à atividade turística.

Sabe-se que um depende do outro: o turismo em si é um pacote de serviços (agências de viagem, companhias aéreas, receptivo e outros). De modo geral, todos os profissionais que fazem o serviço acontecer, de certa forma trabalham para obter ótimos resultados. Na maioria das vezes, os eventos chamam o turismo, pois cada um deles alavanca uma série de serviços no trade turístico, desde a organização e planejamento até a realização e utilização de hospedagem, receptivo e serviços de alimentação, dentre tantos outros demandados, conforme o tipo de realização.

O segmento da Terceira Idade procura certos tipos de eventos como uma forma de reconstruir padrões de vida. Normalmente, tais atividades têm levado essas pessoas a uma melhor qualidade de vida, criando novos valores, novas maneiras de pensar, de sentir e agir, produzindo a imagem de um indivíduo socialmente produtivo e capaz de contribuir com suas experiências, habilidades e sensibilidade para a melhoria da sua existência.

De modo geral, os eventos têm criado novas oportunidades de integração, participação e vivência dos idosos na sociedade, ajudando, através de diferentes atividades, a vencer a incapacidade de lidar com diversas perdas, e dando estimulo ao desenvolvimento da criatividade. (Cadernos do CEAM, 2000, p 19).

Os eventos fazem parte de um conjunto de atividades profissionais desenvolvidas com o objetivo de alcançar um público alvo. Ocorrem por meio do lançamento de algum produto, ou lançamento de alguma pessoa na mídia, empresa ou entidade visando estabelecer ou restabelecer algo.

Segundo Matias (2001, p 61), eles podem ser classificados em relação ao público:

-Eventos fechados: ocorrem dentro de determinadas situações específicas e com público alvo definido;

-Eventos abertos: podem ser divididos em abertos por adesão e abertos em geral. O primeiro é aquele apresentado e sujeito a um determinado segmento populacional, que tem a opção de aderir mediante inscrição gratuita ou pagamento de taxa de participação. O segundo é aquele que atinge todas as categorias de público. 
Quanto à Terceira Idade, os eventos podem acontecer em ambos os casos previstos nessa classificação, havendo diversas possibilidades para sua organização.

Ainda segundo Matias (2001, p 61), os eventos classificam-se em relação à área de interesse, como:

-Artístico: relacionado a qualquer manifestação de arte ligada à música, pintura, poesia, literatura e outras;

-Científico: trata de assuntos referentes às ciências naturais e biológicas;

- Cultural: ressalta os aspectos de determinada cultura, para conhecimento geral ou promocional;

-Cívico: trata de assuntos ligados à pátria;

-Desportivo: ligado a qualquer tipo de evento do setor esportivo, independente de sua modalidade;

-Folclórico: trata de manifestações de culturas regionais de um país, abordando lendas, tradições, hábitos e costumes típicos;

-Lazer: proporciona entretenimento ao seu participante;

-Promocional: promove um produto, pessoa, entidade ou governo, quer seja promoção de imagem ou apoio de marketing;

- Religioso: trata de assuntos religiosos, seja qual for o credo;

- Turístico: explora os recursos turísticos de uma região ou país, por meio de viagens de conhecimento profissional ou não.

Quanto aos eventos direcionados à Terceira Idade, a maioria dos tipos apresentados apresenta grandes possibilidades de realização. Talvez o menos provável de acontecer seja o Promocional, pois, em termos de marketing e comércio, os idosos parecem ser pouco considerados.

Os eventos também podem ser classificados conforme suas características e peculiaridades. Os seus tipos mais comuns relacionados à Terceira Idade são:

-concurso: sua principal característica é a competição, podendo ser aplicado a diversas áreas: artística, cultural, desportiva, científica e outras. Deve ser coordenado por uma comissão organizadora, que estabelecerá o regulamento, a premiação e o júri;

-coquetel: reunião de pessoas cujo objetivo é a comemoração de alguma data ou acontecimento. Nesse tipo de evento são oferecidas bebidas e canapés, que devem ser servidos de forma adequada para satisfazer a maioria. É um evento de curta duração, nunca devendo ultrapassar uma hora e meia;

- desfile: evento que se classifica na categoria promocional. Geralmente é promovido por confecções para a apresentação de seus produtos. As condições básicas para seu sucesso são a escolha adequada dos 
convidados, dos produtos a serem mostrados, dos manequins (demonstradores), da trilha sonora e uma divulgação eficiente;

-encontro: reunião de pessoas de uma categoria para debater sobre temas antagônicos, apresentados por representantes de grupos participantes, necessitando de um coordenador para resumir e apresentar as conclusões dos diversos grupos;

-feira: exibição pública com o objetivo de venda direta ou indireta, constituída de vários estandes, montados em lugares especiais, onde se colocam produtos e serviços;

-happy-hour: reunião de fim de tarde (coquetel/drinque), promovida por bares e restaurantes, caracterizada por disputas (dado, palitinho, dominó e outras) entre maîtres e clientes, nas quais quem ganha não paga a conta;

-mostra: exposição itinerante;

- oficina: evento semelhante ao workshop, mais utilizado pela área educacional, porque proporciona a construção do conhecimento;

-salão: destinado a promover e divulgar produtos e informar sobre eles, com o intuito de criar para os consumidores uma imagem positiva da instituição promotora. Não possui finalidades comerciais imediatas: seu objetivo principal é a promoção institucional. (Matias, 2001, p 63)

Os eventos realizados para a Terceira Idade devem possuir algum diferencial, porque essa fração é muito exigente, e, quando se trata de atividades de puro lazer, tudo muda. Os profissionais que trabalham com esse tipo de evento sabem que hoje nada pode ocorrer de errado, e que, para os idosos, qualquer lazer é como se fosse o primeiro, na medida que, para eles, o mais importante é o bem estar e a qualidade de vida.

\subsection{TERCEIRA IDADE}

De acordo com Debert (1998), a expressão Terceira Idade originou-se na França, com a criação da Université du Troisième Âge (Universidade da Terceira Idade) na década de 1970. Já o critério cronológico de tipificação do indivíduo idoso foi consensualmente definido na ocasião da Assembléia Mundial sobre o Envelhecimento, evento promovido pela Organização Mundial de Saúde (OMS) órgão vinculado à Organização das Nações Unidas (ONU) - na cidade de Viena em 1982. Os parâmetros adotados para determinar o ingresso do ser humano nessa 
fase foram os de 65 anos para os países desenvolvidos, e de 60 anos para aqueles em via de desenvolvimento, tomando por princípio a expectativa de vida das populações. Em 2000, a ONU acabou adotando 60 anos como critério geral para designar a pessoa idosa, objetivando padronizar os percentuais estatísticos.

Alguns pesquisadores que estudam a velhice atribuem essa expressão a uma forma de tratamento para as pessoas de mais idade, expressão essa que ainda não adquiriu uma conotação depreciativa, não estando associada, portanto, com uma idade cronológica precisa. Atualmente, o termo Terceira Idade vem sendo substituído também por Melhor Idade.

Prefere-se, no caso deste estudo, compreender o envelhecimento como fenômeno intrínseco à experiência humana, mais ligado à idéia de continuidade do que à noção de finalidade (término) e fragmentação. Nesse sentido, compactua-se com as concepções de Simone de Beauvoir (1990, p 17):

A velhice não é um fato estático; é o resultado e o prolongamento de um processo. Em que consiste esse processo? Em outras palavras, o que é envelhecer? Esta idéia está ligada à idéia de mudança. Mas a vida do embrião, do recém-nascido, da criança é uma mudança contínua. Caberia concluir daí, como fizeram alguns que nossa existência é uma morte lenta? É evidente que não. Um tal paradoxo desconhece a essencial verdade da vida; esta é um sistema instável no qual, a cada instante, o equilíbrio se perde e se reconquista: é a inércia que é o sinônimo de morte. Mudar é a lei da vida.

Isto posto, e não obstante se saber que a escolha de uma terminologia envolve um certo grau de arbitrariedade, foi aqui adotado o termo Terceira Idade em razão de seu largo uso do dia-a-dia e na literatura científica.

Para Debert (1998), a Terceira Idade é um elemento ativo no processo de reprivatização da velhice - ou seja, a transformação desta em uma responsabilidade individual -, pois a conquista de experiências inovadoras e bem-sucedidas não deixa espaço para situações de dependência e abandono (tão comuns em instituições caritativas que abrigam idosos). Conclui Debert que, para fazer parte da Terceira Idade, o idoso precisa enquadra-se e adequar-se num estilo de vida de consumo específicos e direcionados, com possibilidades econômicas e psico-motoras de praticar atividades de lazer e turismo. Assim, a Terceira Idade acaba por se constituir em um ator público, e o envelhecimento - tido agora como algo positivo -, num novo mercado de consumo. 


\subsection{ASPECTOS DEMOGRÁFICOS}

A Pesquisa Nacional por Amostra de Domicílio de 2005 indica que o número de pessoas de 60 anos ou mais é superior a 18 milhões, correspondendo a quase $10 \%$ da população brasileira - um aumento superior à cinco milhões de pessoas entre 1995 a 2005 -, cifra que cresce ano a ano.

Os estudos indicam que a porcentagem de pessoas idosas é maior nas regiões mais desenvolvidas. Contrariamente, o crescimento nos países em desenvolvimento é mais rápido, fazendo com que a transição de uma estrutura etária jovem para velha ocorra em mais tempo.

Outro aspecto relevante é que a própria população com mais de 60 está envelhecendo, pois as projeções indicam que a faixa de pessoas com 80 anos ou mais é a que tem crescimento mais acelerado, e representarão, em 2050,19\% da população idosa total.

No Brasil, como afirma Paschoal (2000), a concepção ainda vigente para muitos de que se é um "país de jovens", sendo o envelhecimento populacional associado a países mais desenvolvidos da Europa e América do Norte, não corresponde por completo à realidade do país.

De acordo coma a Síntese dos Indicadores Sociais - 2006 (IBGE, 2005), cujos dados tiveram como base a Pesquisa Nacional por Amostra de Domicílios de 2005, foi elaborado o quadro a seguir, onde consta a população residente no Brasil, na Região Centro Oeste e Distrito Federal, por grupo de idade a partir de 60 anos, apontando a participação dessas pessoas na população total. 
Quadro 1: Quantidade e percentual de pessoas residentes com 60 anos ou mais (em relação à população total).

\begin{tabular}{|c|c|c|c|}
\hline ESPECIFICAÇÃO & POPULAÇÃO TOTAL & TOTAL ABSOLUTO & TOTAL RELATIVO \% \\
\hline Brasil & 184.388 .620 & 18.193 .915 & $9,9 \%$ \\
\hline Centro Oeste (1) & 13.040 .246 & 1.020 .625 & $7,8 \%$ \\
\hline Distrito Federal & 2.337 .078 & 149.559 & $6,4 \%$ \\
\hline
\end{tabular}

(1) Composta pelos Estados: Mato Grosso do Sul, Mato Grosso, Goiás e Distrito Federal. Fonte: Síntese de Indicadores Sociais - 2006 (IBGE, 2005).

Ao serem verificados os indicadores de esperança de vida, fecundidade, natalidade e mortalidade no próximo quadro, relativos ao Brasil e o Centro Oeste do país no ano de 2005, pode-se constatar que as tendências apontadas pelas projeções vêm se concretizando.

Quadro 2: Esperança de vida ao nascer, por sexo, taxa de fecundidade e taxa de mortalidade.

\begin{tabular}{|c|c|c|c|c|c|c|}
\hline \multirow{2}{*}{ ESPECIFICAÇÃO } & \multicolumn{3}{|c|}{$\begin{array}{c}\text { ESPERANÇAS DE VIDA AO } \\
\text { NASCER }\end{array}$} & $\begin{array}{c}\text { TAXA DE } \\
\text { FECUND. } \\
\text { TOTAL }\end{array}$ & $\begin{array}{c}\text { TAXA } \\
\text { BRUTA DE } \\
\text { NATAL. }\end{array}$ & $\begin{array}{c}\text { TAXA } \\
\text { BRUTA DE } \\
\text { MORTAL. }\end{array}$ \\
\cline { 2 - 4 } Brasil & 71,9 & 68,1 & 75,8 & 2,3 & $20,4 \%$ & $6,3 \%$ \\
\hline Centro Oeste (1) & 73,2 & 69,8 & 76,7 & 2,0 & $18,5 \%$ & $5,2 \%$ \\
\hline Distrito Federal & 74,9 & 71,2 & 78,7 & 1,9 & $18,8 \%$ & $4,3 \%$ \\
\hline
\end{tabular}

(1) Composta pelos Estados: Mato Grosso do Sul, Mato Grosso, Goiás e Distrito Federal. Fonte: Síntese de Indicadores Sociais - 2006 (IBGE, 2005).

Se, sob o enfoque demográfico, o envelhecimento da população vem ocorrendo de forma rápida e irreversível, no que diz respeito à evolução das representações da sociedade com relação à velhice não se pode dizer o mesmo. 


\section{MARKETING}

Neste capítulo serão abordados aspectos relativos ao marketing, à segmentação de mercado, ao comportamento do consumidor da Terceira Idade, à estrutura e à adequação da cidade de Brasília ao lazer para o idoso.

O marketing ganhou uma ascendência inimaginável, tornou-se quase o valor supremo nos dias atuais. Por isso mesmo, perdeu-se um pouco o pé no chão que lhe á tão necessário. Ele é um impulsor da atividade econômica entre outras, e um criador de empregos. Kotler (2001, p 116)

Portanto, quanto à afirmação de Kotler, é importante focalizar o marketing dentro de um contexto mais amplo, de inegável relevância, embora seja apenas um dos elementos, dentre tantos, capazes de levar uma atividade econômica ao sucesso. Nesse contexto se insere o turismo, com o marketing despontando como uma importante ferramenta para o desenvolvimento em todos os níveis: local, regional e nacional.

Por isso que, conforme a OMT (2003), para concorrer no mercado turístico, as organizações dos setores público e privado devem saber quem são os seus clientes e o que eles querem.

\subsection{SEGMENTAÇÃO DE MERCADO}

O processo de determinação de grupos com características de consumo é conhecido como segmentação de mercado. Segundo Kotler (2000, p 278), este se define como um grande grupo identificado a partir de suas preferências, poder de compra, localização geográfica, atitudes e hábitos de compra semelhantes.

Segmentar o mercado é dividi-lo em grupos com características e interesses semelhantes, para que, em seqüência, possa-se definir o público alvo e o perfil da clientela final. 
Conhecer os desejos e necessidades de cada cliente é importante, pois, a partir desse ponto, poder-se-á desenvolver a melhor maneira para trabalhar-se com cada grupo, criando-se uma identidade junto ao cliente, que fará com que ele se sinta importante e valorizado. Assim, quando se fala em segmentação, não se pode esquecer que nenhum consumidor é igual ao outro, e que não se pode tratar a todos da mesma forma.

O mercado turístico como um todo pode ser segmentado por país, região, cidade ou mesmo por ponto turístico. Pode sê-lo, ainda, de acordo com a idade ou classe social do consumidor-turista, ou mesmo em relação ao tipo de turismo praticado.

Um fator importante e determinante para a segmentação é a concorrência, pois leva à busca de diferenciais que garantam uma clientela identificada com seu produto. Portanto, a empresa que conhecer seus clientes ou seu mercado potencial conseguirá maiores vantagens nas vendas, pois esses dados ajudarão a direcionar melhor seus recursos e adequar os produtos ao mercado visado. Segundo Beni (1998, p 149), a estrutura do mercado turístico é definida como a parte da economia que estuda e analisa a atividade econômica do turismo, baseada em um mercado onde confluem a oferta de produtos e serviços turístico, e a demanda, que está interessada e motivada em consumi-los.

A opção de segmentar - ou não - ocorre principalmente pelo aumento da oferta de produtos, pela expansão dos mercados, e, também, pela vontade de o cliente ter seus desejos - muitas vezes específicos - atendidos.

A segmentação divide o mercado segundo um determinado critério preestabelecido pelo interesse da empresa, facilitando a relação com o consumidor pelo melhor conhecimento que se consegue adquirir sobre ele.

Portanto, a segmentação enfatiza mais o mercado, e não o setor de atividade, os canais de distribuição ou os produtos, pois é uma técnica estratégica. Existem várias maneiras de segmentar um determinado mercado, como citados no Quadro 3. 
Quadro 3. Formas de segmentar o mercado

\begin{tabular}{|l|l|}
\hline \multicolumn{1}{|c|}{ MODALIDADE } & \multicolumn{1}{|c|}{ CRITÉRIOS } \\
\hline Geográfica & $\begin{array}{l}\text { Extensão do mercado potencial, concentração geográfica, } \\
\text { transporte e acesso, polarização, bairro e ruas, tráfego, centro } \\
\text { de compras. }\end{array}$ \\
\hline Demográfica & $\begin{array}{l}\text { Idade, sexo, domicílio, família, ciclo de vida (jovem, adulto, } \\
\text { idoso). }\end{array}$ \\
\hline Socioeconômica & $\begin{array}{l}\text { Classe de renda, instrução, ocupação, status, migração, } \\
\text { mobilidade social. }\end{array}$ \\
\hline Padrões de consumo & Freqüência de compra, local de comprar, lealdade às marcas. \\
\hline Benefícios procurados & $\begin{array}{l}\text { Satisfação sensorial, prestígio social, emulação-preço } \\
\text { favorável, qualidade/durabilidade, redução de custos, } \\
\text { atendimento e serviços. }\end{array}$ \\
\hline Estila de vida & $\begin{array}{l}\text { Expectativa de vida, uso do tempo, interesses predominantes, } \\
\text { participação em eventos e agrupamentos sociais, uso do } \\
\text { dinheiro, amizades e relações pessoais. }\end{array}$ \\
\hline Personalidade & $\begin{array}{l}\text { Bases culturais, atitudes e valores, liderança, agentes de } \\
\text { mudanças. }\end{array}$ \\
\hline Caracterização econômica & $\begin{array}{l}\text { Setor de atividade, tamanho das empresas, atuação de } \\
\text { concorrentes, acessibilidade, usos e aplicações, unidade de } \\
\text { decisão de compra derivada. }\end{array}$ \\
\hline
\end{tabular}

Fonte: Pimenta e Richers. (1991)

A segmentação é uma estratégia de marketing usada na administração de bens e serviços. Como o turismo insere-se nesse setor da economia, as atrações usadas no marketing turístico serão determinadas pelas características do produto no caso, o produto turístico -, conforme o quadro seguinte.

Como pode-se observar no Quadro 4, o produto turístico tem características especiais que devem ser levadas em conta quando estabelecem-se as estratégias de segmentação. Com o uso destas, torna-se possível conhecer os principais destinos geográficos, os tipos de transporte, o perfil do turista (faixa etária, capacidade de compra, condições sociais, escolaridade, ocupação, estado civil, motivações, etc.), o ciclo de vida do produto e a elasticidade no preço da oferta e da demanda, facilitando, assim, o atendimento dos desejos dos turistas. 
Quadro 4. Comparação entre bens e produtos gerais e produto turístico.

\begin{tabular}{|c|c|}
\hline BENS E PRODUTOS & PRODUTO TURÍSTICO \\
\hline $\begin{array}{l}\text { São materiais, tangíveis, e podem ser } \\
\text { avaliados previamente por uma amostra. }\end{array}$ & $\begin{array}{l}\text { É material e intangível, podendo ser visto } \\
\text { antes da compra por meio de sua imagem. }\end{array}$ \\
\hline $\begin{array}{l}\text { A produção ocorre, em geral, anteriormente } \\
\text { ao consumo e em local distinto. }\end{array}$ & $\begin{array}{l}\text { A produção e o consumo ocorrem no mesmo } \\
\text { lugar. }\end{array}$ \\
\hline Em geral, podem ser transportados. & $\begin{array}{l}\text { É necessário que o turista se desloque até o } \\
\text { produto, que não pode ser transportado. }\end{array}$ \\
\hline $\begin{array}{l}\text { Podem ser estocados e vendidos a } \\
\text { posteriori. }\end{array}$ & $\begin{array}{l}\text { Não pode ser estocado. Se não for vendido, é } \\
\text { perdido. }\end{array}$ \\
\hline Passíveis de controle de qualidade. & $\begin{array}{l}\text { Dificilmente sua qualidade pode ser } \\
\text { controlada. }\end{array}$ \\
\hline $\begin{array}{l}\text { Não há, necessariamente, uma relação de } \\
\text { complementaridade entre os produtos. }\end{array}$ & $\begin{array}{l}\text { Existe complementaridade entre os elementos } \\
\text { que compõem o produto turístico. }\end{array}$ \\
\hline Demonstram menor sazonalidade. & É mais suscetível à sazonalidade. \\
\hline $\begin{array}{l}\text { São mais fáceis de serem adaptados às } \\
\text { alterações do público consumidor. }\end{array}$ & $\begin{array}{l}\text { É estático, ou seja, é impossível mudar-se a } \\
\text { sua localização, e é difícil alterarem-se as } \\
\text { suas características. }\end{array}$ \\
\hline $\begin{array}{l}\text { São passíveis de transferência por venda ou } \\
\text { doação a outro consumidor. }\end{array}$ & $\begin{array}{l}\text { Uma vez adquirido, não pode ser vendido } \\
\text { novamente pelo turista. }\end{array}$ \\
\hline $\begin{array}{l}\text { Passam a ser uma propriedade do } \\
\text { consumidor. }\end{array}$ & $\begin{array}{l}\text { Não passa a ser propriedade do consumidor } \\
\text { pela compra. O turista, por exemplo, não leva } \\
\text { consigo o hotel, mas as fotos e recordações. }\end{array}$ \\
\hline
\end{tabular}

Fonte: Bacal e Rejowski (1991)

Portanto, torna-se necessário que, na sua administração de marketing, a empresa interligada ao turismo execute uma pesquisa de mercado que poderá reconhecer as destinações turísticas a serem trabalhadas. Quando o resultado apontar para a segmentação de mercado, a estratégia, seja ela o marketing concentrado ou o diferenciado, poderá atingir o seu público alvo e as suas respectivas necessidades, principalmente ao atender melhor aos desejos dos clientes, satisfazendo-os com um produto turístico personalizado, garantindo, assim, a sua fidelização à empresa. 


\subsection{COMPORTAMENTO DO CONSUMIDOR DA TERCEIRA IDADE}

A imagem do segmento hoje denominado Terceira Idade sofreu muitas mudanças ao longo dos anos. Os mais velhos eram praticamente considerados como semi-inválidos em muitas sociedades. Porém, resgatou-se o prestígio dessa fatia de mercado com o tempo. Um maior conhecimento proporcionado por estudos direcionados, relacionados às necessidades de mercado, proporcionou uma autovalorização e novos sentidos para a vida desses cidadãos.

Atualmente, eles transmitem uma nova imagem, associada ao bem estar, à qualidade de vida e ao proveito máximo do tempo. Entretanto, não se consegue obter uma conceituação muito precisa do que venha a ser o segmento da Terceira Idade. Aliás, cada um desses termos, para ser bem aceito, entra em discussão, passando por conceituações e pelo esclarecimento de comportamentos que, diga-se de passagem, estão longe da homogeneidade, ou de enquadrarem-se em padrões pré-estabelecidos. Isso diz respeito a todos os termos que se encontrem dentro da cronologia oficial para a dita Terceira Idade.

Hoje, no Brasil, este ainda é considerado um nicho bastante novo e promissor. O mercado cresce a cada dia, e a toda hora nascem novas oportunidades, gerando-se, nesse âmbito, novas oportunidades e melhorias na qualidade de vida.

Nesse sentido, entre localidades e, também, dentro das próprias comunidades, a Terceira Idade vem investindo em si própria, gerando participação em eventos organizados especificamente para grupos com interesses próximos, praticando atividades como viagens, passeios menos longos, jogos e entretenimentos diversos.

Conforme já ponderado, o comportamento atual dessa parcela da população difere-se bastante daquele de há alguns anos atrás. Antes, dedicavam-se à família de forma integral: marido, esposas, filhos e netos. Hoje, aprenderam a autovalorização, a deixar um pouco de lado os serviços e afazeres domésticos, e deramse uma nova oportunidade de viver de forma alegre e saudável, o que inclui o 
turismo e atividades relacionadas diretamente às diversas formas de participação em diferentes tipos de eventos.

A Terceira Idade é um nicho com grande potencial para usufruir viagens e lazeres em geral. O seu perfil psicossocial e de consumo faz com que eles sejam indivíduos interessados e bem dispostos, tanto na parte física como mental, não deixando de viver novas experiências e de adquirir novos conhecimentos. Por isso é que esse segmento tende a crescer cada vez mais.

Os mais velhos valorizam especialmente o bem-estar e a satisfação pessoal, e gostam de investir cada vez mais em produtos que satisfaçam suas expectativas. Observa-se também que a Terceira Idade, tendo capacidade para investir, é um público que não costuma ter restrições em relação a datas, gosta de adquirir lembranças dos lugares que visita, não mede gastos com conforto, e costuma comprar pacotes completos com hospedagem. Ela possui uma flexibilidade de horários, e é responsável pelos lucros do mercado nos períodos de baixa temporada, representando, para muitas localidades, os clientes mais ativos do mercado turístico.

No que diz respeito ao comportamento dos turistas da Terceira Idade, Garcia (2001) aponta as seguintes preferências:

- Preferem realizar atividades turísticas em grupos, mas não necessariamente com indivíduos da mesma idade;

-São mais críticos e seletivos, buscando qualidade;

-Visam conforto e benefícios;

-Procuram lugares novos, e se relacionam mais;

-São exigentes e reivindicativos, informados e conscientes dos seus direitos;

-Privilegiam a qualidade de serviços e a relação qualidade/ preço;

-Não querem ser tratados como incapazes, mas com respeito, (não por sua condição de idoso, mas de clientes em absoluta igualdade com os demais).

A adequação das ofertas, portanto, já conta com alguns parâmetros que podem servir de ponto de partida para a captação dessa clientela, sem perde-se a perspectiva de que a flexibilidade nas ações, as condições competitivas de preço e o alto grau de atenção e de responsabilidade da empresa são fatores que intervêm nas decisões de compra. (Garcia, 2001, p 161-162) 
A questão da maior disponibilidade de tempo da Terceira Idade é muito importante se a considerarmos em relação à questão da sazonalidade. O caráter sazonal do turismo, ou seja, a reduzida demanda de turistas nos períodos de baixa temporada, implica, para inúmeros locais, a queda da qualidade da oferta turística em geral, pois esse fenômeno provoca dificuldades econômicas e operacionais em importantes setores de sustentação da atividade turística, como transporte, meios de hospedagem, gastronomia, segurança, manutenção da infra-estrutura básica dos núcleos receptores, etc. Percebendo essa lacuna, Bacal (2003, p 77) chama a atenção para a necessidade desse criar, então, "instrumentos capazes de minimizar os efeitos da defasagem entre volume dos fluxos turísticos nas alta e baixa estações".

Dessa forma, o incentivo ao turismo da Terceira Idade é tido como uma alternativa para minimizar, senão para resolver o problema, já que esse segmento pode constituir um fluxo permanente nas baixas temporadas, garantindo, então, a partir de viagens organizadas, a taxa de ocupação da rede hoteleira e a utilização de equipamentos e serviços turísticos e não turísticos durante todo o ano.

Os integrantes da Terceira Idade querem uma vida saudável, com mais qualidade e, por isso, não aceitam qualquer tipo de lazer ou atividade. Preferem aquilo que possa proporcionar-Ihes envolvimentos, e que lhes dêem a sensação de serem úteis no que estão realizando.

\subsection{BRASÍLIA: ADEQUAÇÃO AO LAZER DA TERCEIRA IDADE}

Brasília é considerada a capital brasileira do turismo de eventos e negócios. A cidade apresenta diversos atrativos, e equipamentos turísticos necessários para a realização de um evento de sucesso. Existem várias associações e organizadores de eventos tentando investir no segmento da Terceira Idade. O SESC, por exemplo, realiza bastantes atividades voltadas aos idosos, com o objetivo de melhorar-lhes a qualidade de vida, almejando sempre trazer-lhes satisfação e valorização. 
Hoje, o público idoso escolhe vir a Brasília por vários motivos. Primeiramente, por ser uma cidade jovem, calma, espaçosa, com opções de lazer e cultura, e por ter características naturais.

\subsubsection{Infra-estrutura da cidade}

A rodoviária situa-se no centro geográfico de Brasília, e nela cruzam-se os eixos rodoviário e monumental. Ela foi projetada por Lúcio Costa, que concebeu um conjunto de plataformas em quatro níveis. Na plataforma inferior ficam os pontos de ônibus que ligam o Plano Piloto a todos os lugares do Distrito Federal e do Entorno. Nas plataformas intermediárias, a estação divide a Asa Norte e Asa Sul da cidade, e, na plataforma superior, estão localizados os dois setores de diversões, hoje dominados por dois shoppings - o SDS do lado sul e, do lado norte, o Conjunto Nacional, o dos mais tradicionais de Brasília.

Brasília, por ser a capital do Brasil, merece uma estação rodoviária mais estruturada e organizada do que a atual. As pessoas que a freqüentam sabem das dificuldades e da falta de higiene do local, e percebem nela vários defeitos, tais como ambulantes em todos os lugares, lixo espalhado no chão, mendigos e pedintes, atrasos nos horários de ônibus e mau cheiro. Não há sequer um local para informação, sendo que os banheiros estão em péssimas condições, as escadas rolantes não funcionam, os elevadores são precários, há roubos constantes e falta de segurança generalizada. Por ser um local de livre acesso, e onde várias pessoas circulam todos os dias, ela deveria contar com uma segurança reforçada.

Especificamente no caso dos idosos, os problemas aumentam, pois muitas vezes esses são analfabetos, ou possuem problemas de visão, e, com a falta de um serviço razoável para informações e orientação, eles sofrem ao tentarem se orientar no edifício.

A rodoviária foi planejada numa ótima localização, e visava atender o transporte distrital e intermunicipal/interestadual. Hoje, porém, limita-se somente ao Distrito Federal e Entorno, e, ainda assim, parece estar visivelmente inadequada e 
obsoleta, em termos de capacidade e qualidade de atendimento, para a infinidade de pessoas que dela dependem diariamente.

A rodo-ferroviária está localizada no extremo oeste do Eixo monumental, a 10 km do centro do Plano Piloto, e foi inaugurada em 22 de dezembro de 1980. Construída numa área de aproximadamente 36 mil metros quadrados, atendia somente o fluxo de transporte ferroviário de carga, mas hoje abrange também o transporte rodoviário interestadual para todas as capitais e principais cidades brasileiras.

Atualmente, a rodo-ferroviária apresenta-se em estado precário. O idoso que utilizar dos serviços deste edifício sentir-se-á desconfortável, pois ficará em pé até a chegada do ônibus, e deparar-se-á, por fim, com a desorganização e o despreparo do atendimento e dos funcionários.

Outro aspecto sobre o qual reclama-se bastante é a sua localização, muito afastada das regiões centrais. A cidade mais próxima da rodo-ferroviária é Cruzeiro, e a acessibilidade de outros lugares ao terminal é dificultada devido ao seu isolamento.

A imagem do terminal rodo-ferroviário junto aos brasilienses não é das melhores. Fala-se muito em falta de limpeza e higiene, dentre outras mazelas, e a população não considera-o um terminal "decente", ou à altura de uma Capital Federal.

A companhia do Metrô foi criada para oferecer à população um transporte coletivo público de qualidade, com eficiência, conforto, limpeza, regularidade, rapidez e segurança, preservando a vida, o meio ambiente e o patrimônio cultural da cidade. Foi inaugurado em 31 de março de 2003 com uma grande comemoração da população, pois antes não se tinha um transporte tão rápido e prático. Hoje, ele conta com 14 estações, a saber:

- Central / Galeria / 114 Sul / Asa Sul/ Shopping / Feira do Guará / Arniqueiras / Águas claras / Concessionárias / Praça do Relógio / Taguatinga Sul / Furnas / Samambaia Sul / Terminal Samambaia.

Os horários de funcionamento do metrô não constituem uma tabela fixa, pois os intervalos variam de 10 a 20 min, dependendo da estação, e de acordo com a demanda. 
De acordo com uma entrevista concedida por telefone pelo servidor Eduardo Santos, da Companhia do Metrô de Brasília, pôde-se conhecer os cuidados que as estações tomam em relação ao público idoso:

- Assentos preferenciais: servem para idosos, gestantes e deficientes, mas, apesar dos avisos sobre a exclusividade das cadeiras, é utilizado por pessoas que não se enquadram naquelas três categorias. Esses assentos não são obrigatórios, e, por isso, muitas vezes não são respeitados;

- Atendimento médico (serviço de transporte): no metrô, há um serviço que é prestado para todos (serviço de socorro médico); em caso de indisposição, profissionais treinados encaminham o paciente para 0 hospital mais próximo.

Nas suas dependências também existem adaptações - corrimão nas escadas, elevadores e escadas rolantes - para todos os tipos de situação, embora para a utilização do elevador seja necessária a presença de um funcionário da companhia. Além disso, todos os empregados do metrô são treinados para todas as situações, desde o funcionamento e limpeza do meio de transporte, até o trato com pessoas. Existe, para os idosos, um acompanhamento durante as viagens, no caso de dificuldade extrema ou indisposição.

Para facilitar a vida dos idosos, há a necessidade de planejar tudo o que deseja-se fazer, pois Brasília não é muito amigável para com os pedestres por conta de sua estrutura, que exige sempre o uso de algum meio de transporte, principalmente motorizado. Neste caso, é oferecido um serviço de receptivo para o visitante, que consiste num deslocamento guiado, com o objetivo de realizar passeios, lazer, city tour, ou algum itinerário específico. Sua principal função é apresentar a cidade, e é por meio dele que, normalmente, estabelece-se o primeiro contato com o cliente/turista. Caso ele seja responsável por este primeiro contato, é dali que sairá toda a informação sobre a localidade.

Portanto, para trabalhar como prestador do serviço de receptivo, o profissional precisa conhecer bem a cidade e seus atrativos, assim como os meios de hospedagem, gastronômico, hoteleiro e outros oferecidos, sem contar a necessidade de comunicar-se fluentemente em pelo menos uma língua estrangeira. 
Em Brasília, o receptivo oferece vários destinos e atrações. São mais de oito itinerários para as localidades mais próximas, como Goiânia, Pirenópolis, Anápolis, Cristalina, Itiquira, Alto Paraíso, Chapada dos Veadeiros e Caldas Novas, cobrandose por passageiro. Os valores podem variar de $\mathrm{R} \$ 380,00$ a $\mathrm{R} \$ 690,00$, dependendo do trecho. Existem também roteiros de passeios específicos, como, por exemplo, um pacote de 5 horas, sendo incluídos city tour e almoço.

Existem vários outros atrativos oferecidos por empresas de receptivo em Brasília. Para contratar uma empresa é aconselhável passar por uma agência de turismo que conheça, ou que comercialize este tipo serviço, e que possa explicar sobre as vantagens e desvantagens com maior credibilidade.

A maior parte dos Meios de Hospedagem de Brasília estão localizados na região central do plano piloto, próximos à rodoviária, no cruzamento entre os eixos monumental e rodoviário. Dividem-se entre Setor Hoteleiro Sul e Setor Hoteleiro Norte e, em sua grande maioria, são hotéis de luxo voltados aos viajantes executivos. É de conhecimento geral que a cidade recebe turistas de muitas regiões do Brasil, e que estes trabalham na capital durante a semana. No entanto, não mantêm moradia em Brasília, pois vêm geralmente a trabalho e a negócios. A média de permanência desses é de dois a três dias, normalmente de segunda a quinta feira.

Existem também as pousadas, localizadas na Via W3 Sul, uma avenida destinada ao comércio, este com bastante variedade de lojas e produtos. Essas pousadas são muitíssimo mais simples e têm preços acessíveis. De certa forma, ter o comércio por perto é um conforto a mais para os hóspedes desses estabelecimentos.

Brasília absorveu influências das mais diversas culturas do mundo e do país, e o fato de ter atraído, e de ainda atrair brasileiros de todos os cantos, e de reunir representantes oficiais de vários países, fez com que a cidade desenvolvesse uma verdadeira rede gastronômica, com muita qualidade e diversidade.

Pode-se encontrar na cidade sofisticados restaurantes internacionais, assim como genuínos representantes das cozinhas regionais e de diversos países. São mais de 3.500 estabelecimentos de alimentos e bebidas, para todos os paladares. Diante deste fato, a cidade possui atualmente uma grande diversidade de atividades 
culturais, principalmente quando se trata da área gastronômica, fatores esses que permitem fazer de Brasília um grande atrativo turístico.

Os restaurantes da Capital não trabalham somente para atingir somente um tipo de clientela, mas apostam na diversificação. Por isso, em se tratando da Terceira Idade, não se encontra em Brasília locais específicos para atender a esse segmento, mas sim, locais com muita qualidade e um ótimo atendimento, preparados para adaptar seu cardápio diante das necessidades e exigências deste público, pois os idosos costumam apreciar um atendimento atencioso e especializado. 


\section{METODOLOGIA}

A perspectiva de desenvolvimento do turismo para a Terceira Idade foi o aspecto primordial que impulsionou a realização desta pesquisa. Entretanto, ao iniciar-se a busca de literatura relativa ao assunto, constatou-se que pouco existia sobre turismo para a Terceira Idade.

Severino (2000, p 11) conceitua metodologia como: "O 'Methodo' significa caminho, 'logia' significa estudo. É um conjunto de abordagens, técnicas e processos utilizados pela ciência para formular e resolver problemas de aquisição objetiva do conhecimento, de uma maneira sistemática".

A metodologia utilizada neste trabalho foi a pesquisa exploratória, pois envolveu entrevistas com as pessoas idosas, e os gerentes de associações que possuem experiências e práticas sobre o assunto em questão, além de ter-se procedido uma pesquisa bibliográfica, a partir de materiais já publicados, como livros, artigos de periódicos, internet, monografias, artigos científicos, etc. Também utilizou-se a pesquisa documental, buscando-se por dados secundários em órgãos e associações. Conforme Gil (2002), a pesquisa exploratória tem como objetivo principal o aprimoramento de idéias ou a descoberta de instituições.

As abordagens deste inquérito foram das formas qualitativa e quantitativa, e das maneiras direta e específica, sendo o primeiro tipo aplicado aos gerentes do NEPTI e do SESC, pessoas responsáveis pela promoção de eventos para o público pesquisado. A parte quantitativa foi direcionada à Terceira Idade. Segundo Chizzotti (2000, p 52), as pesquisas quantitativas prevêem a mensuração de variáveis preestabelecidas, procurando verificar e explicar sua inferência sobre outras variáveis, mediante análise da freqüência de incidência e de correlações estatísticas. O pesquisador descreve, explica e prediz. E a pesquisa qualitativa é fundamentada em dados coligados nas interações inter-pessoais, na co-participação das situações dos informantes analisados a partir da significação que estes dão aos seus atos. Neste caso, o pesquisador participa, compreende e interpreta.

O instrumento utilizado na análise quantitativa foi o questionário, que continha uma questão aberta e doze fechadas, aplicadas em forma de entrevista, 
relacionadas ao perfil demográfico e ao mercado da Terceira Idade de Brasília. Conforme Vera (2005), o questionário, numa investigação, é um instrumento ou programa de coleta de dados. Se é confeccionado pelo pesquisador, será preenchido pelo informante.

A coleta dos dados ocorreu no período de 03 março a 23 de março na cidade de Brasília/DF, em locais freqüentados por idosos, como o SESC, o Parque da Cidade, o Parque Olhos d`Água, o Cube do Choro, Shoppings e outros locais.

A amostragem adequada é freqüentemente utilizada para a geração de idéias em pesquisas exploratórias, principalmente. Amostras por conveniência podem ser facilmente justificadas em um estágio exploratório da análise.

No momento da abordagem, apresentaram-se os objetivos da pesquisa aos respondentes, e perguntou-se-lhes se possuíam mais de 45 anos, pois o filtro utilizado na coleta foi que o entrevistado estivesse acima desta idade. Em caso positivo, a pessoa era convidada para participar da pesquisa.

Portanto, obtiveram-se 93 questionários válidos, e, após a coleta, fez-se a tabulação dos dados com o auxilio de planilha eletrônica, e analisaram-se os dados com base em estatística descritiva.

A pesquisa qualitativa, composta por 10 questões abertas, foi aplicada por meio de um instrumento semi-estruturado, entregue individualmente, e aplicado a dois gestores de instituições que trabalham com a Terceira Idade. As entrevistas foram marcadas com os gerentes do SESC e do NEPTI, os quais foram compreensivos e atenciosos, respondendo às questões com naturalidade.

\subsection{ANÁLISE DOS DADOS}

Analisaram-se os dados coletados segundo a estatística descritiva, buscando-se as maiores tendências do segmento, e analisando-se as preferências médias e o perfil do respondente. 


\subsubsection{Perfil do respondente}

O respondente desta pesquisa caracteriza-se por ser do sexo feminino, estar na faixa etária entre 45 e 55 anos, ser residente no Plano Piloto, ser casado e viver com o cônjuge, além de possuir escolaridade de nível superior completo, e estar profissionalmente ativo, com renda média entre 6 a 10 salários mínimos.

\subsubsection{Resultados da entrevista}

Como previsto nos procedimentos metodológicos, por meio das questões iniciais formuladas aos entrevistados, coletaram-se informações que permitissem delinear o perfil do participante dos grupos de Terceira Idade do Distrito Federal.

Gráfico 1 - Gênero

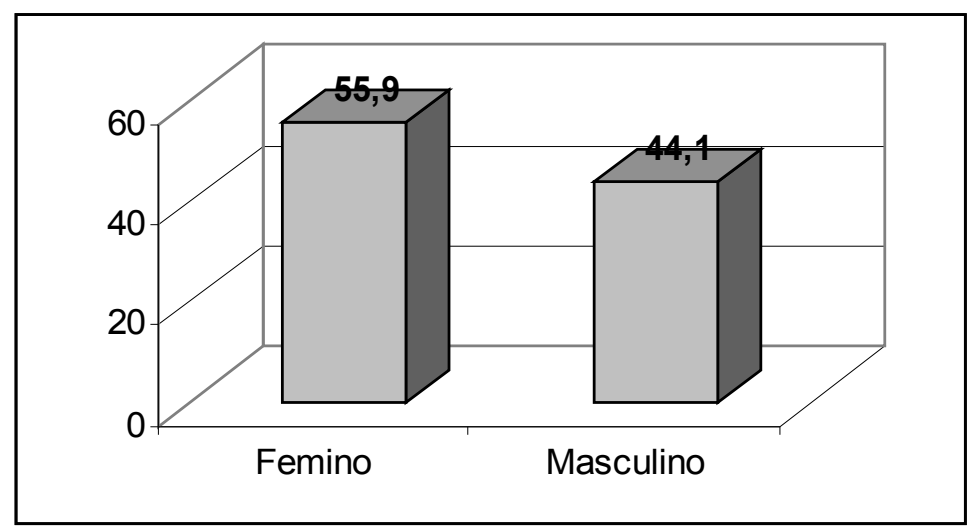

Observando-se $\circ$ Gráfico 1, conclui-se que mais da metade dos entrevistados - ou seja, $55,9 \%$ - são do sexo feminino, e $44,1 \%$ do masculino. De acordo com os dados do Censo 2006 (IBGE, 2007), a população de mulheres é $11 \%$ maior que a de homens. Estudos apontam para a "feminização" do processo de envelhecimento nacional, mostrando grandes distinções entre os contingentes de 
homens e mulheres, sendo estimada, para 2050, a existência de quatorze mulheres para cada dez homens. (Palma, 2000, p 31).

Além dessas evidencias quantitativas, comportamentos diferenciados da mulher e do homem idoso conduzem a uma menor participação masculina nos grupos que se enquadram nas atividades para a Terceira Idade.

Os homens parecem ser mais reticentes que as mulheres idosas quanto se engajar no exercício de novos papéis sociais abertos pela alta modernidade, como por exemplo, [...] participar de grupos de convivência e lazer [...]Goldstein (2004, p 118)

Isso demonstra que as mulheres da Terceira Idade saem de suas casas em busca de vida social e lazer.

Gráfico 2 - Tempo que residem em Brasília

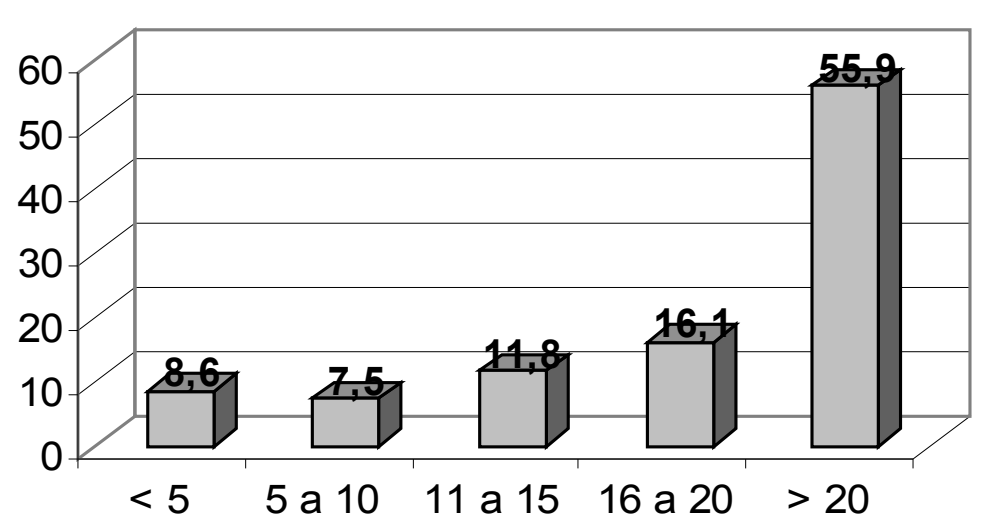

Os dados revelam que a maioria absoluta $(55,9 \%)$ dos respondentes vive em Brasília há mais de 20 anos. Construíram uma história profissional e criaram suas famílias na cidade, portanto, sentem-se socializados e ambientados a ela. 
Gráfico 3 - Estado Civil

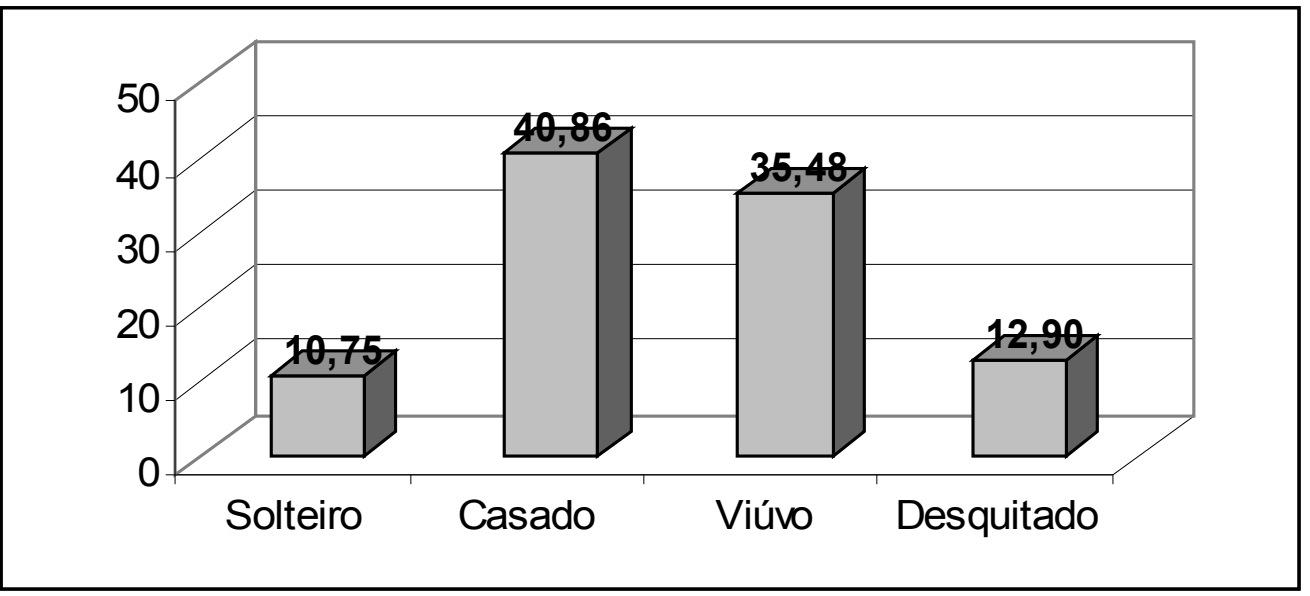

Quanto ao estado civil dos entrevistados, constata-se que a maioria $(40,86 \%)$ é casada, seguida de $35,48 \%$ de viúvos, $12,90 \%$ de desquitados e $10,75 \%$ de solteiros.

Gráfico 4 - Faixa etária

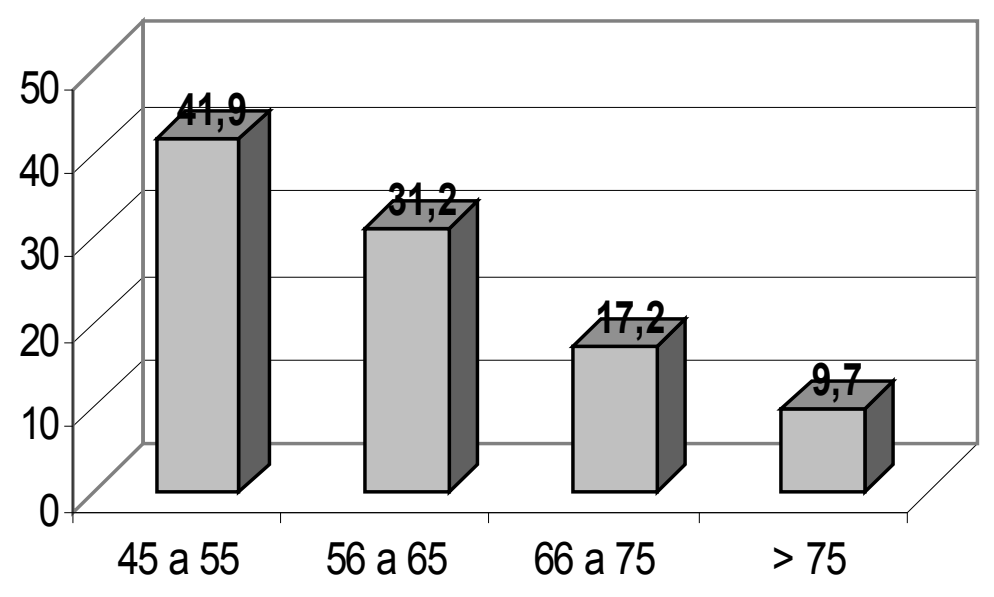

Os dados acima revelam que $44,9 \%$ dos respondentes tem de 45 a 55 anos, seguidos da faixa acima, de 56 a 65 anos, com $31,2 \%$. Optou-se pela idade mínima de 45 anos para diversificar-se a pesquisa, enfatizando-se cada vez mais o objetivo.

Pode se inferir que, quanto mais à pessoa avança na idade, menos ela sai de casa para consumir produtos de lazer e entretenimento. Brasília destaca-se como 
uma das idades com maior expectativa de vida do Brasil, segundo o IBGE (Síntese dos Indicadores Sociais - 2006 /IBGE, 2005).

Gráfico 5 - Status profissional

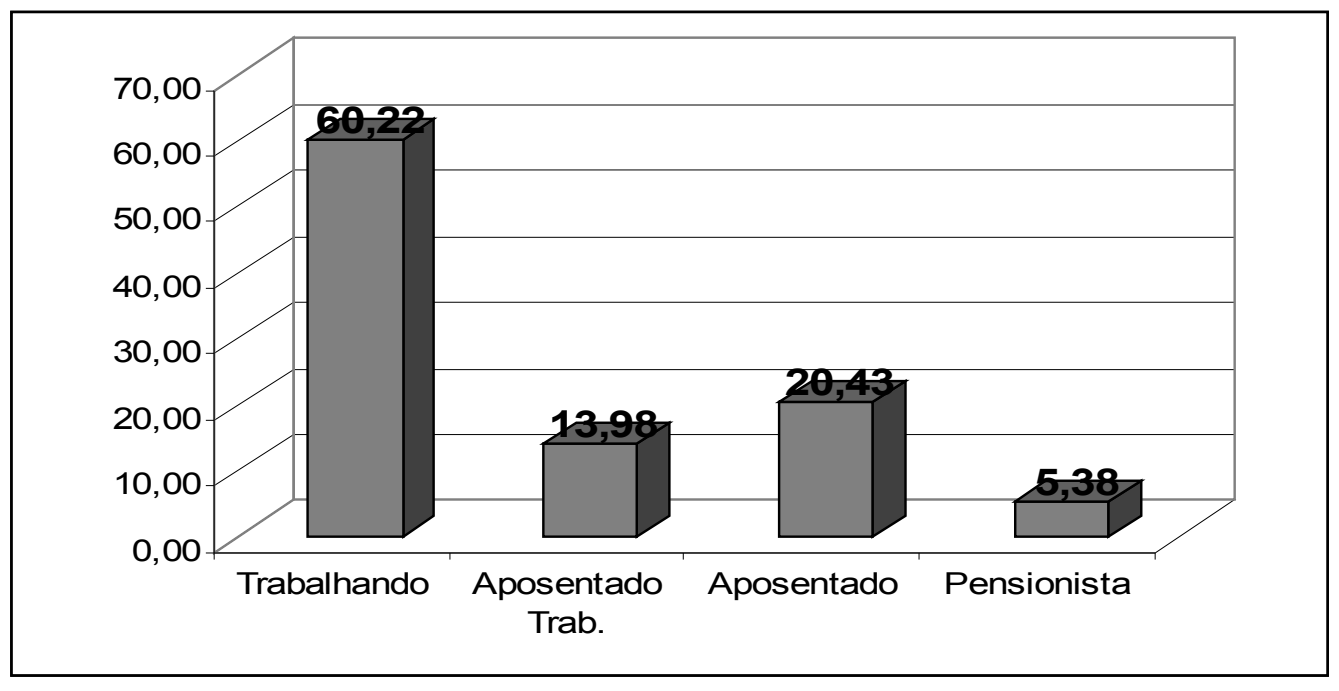

A maioria absoluta dos entrevistados (56\%) trabalha, $13 \%$ estão aposentados e ainda trabalham, 19\% estão aposentados, e 5\% dos respondentes são pensionistas.

Gráfico 6 - Escolaridade

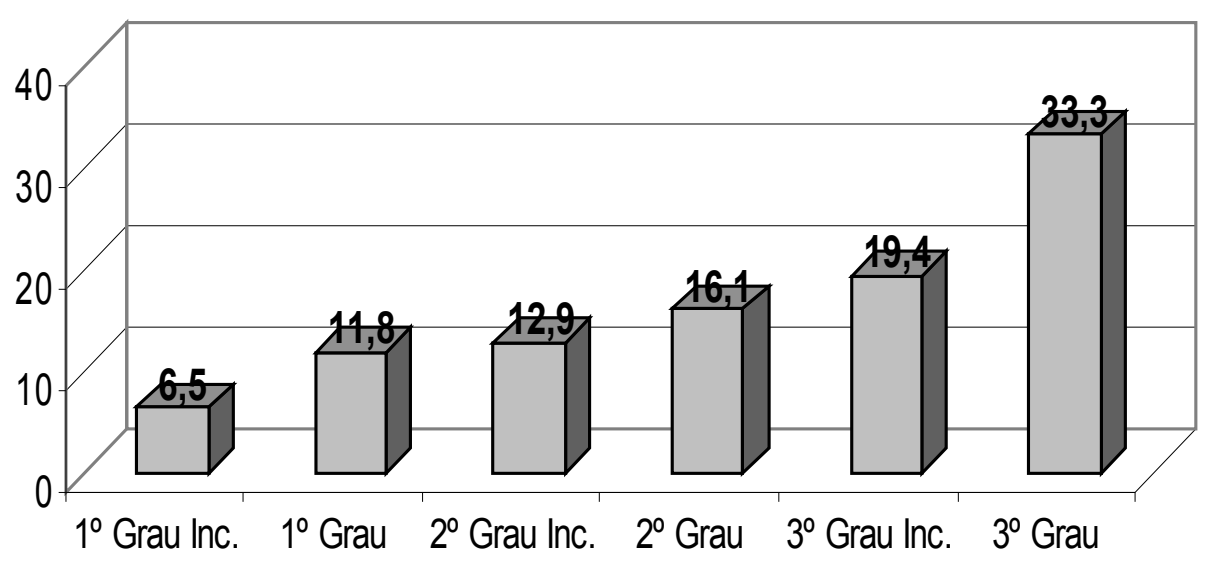

É importante salientar que, do total de informantes, a maioria $(33,3 \%)$ concluiu o $3^{\circ}$ grau. Ressalta-se que a pesquisa foi feita na cidade de Brasília, onde, segundo o IBGE, há uma predominância de pessoas de classe média, e, por conseqüência, sugere-se que elas possuam uma formação educacional mais alta do 
que as populações das cidades satélites. A pesquisa concentrou-se no Plano Piloto, onde a escolaridade e o rendimento mensal são maiores. Isso permite concluir que o grupo apresenta um nível diferenciado, o que se pode-se observar também na classe de renda e no local de moradia.

Gráfico 7 - Rendimento mensal

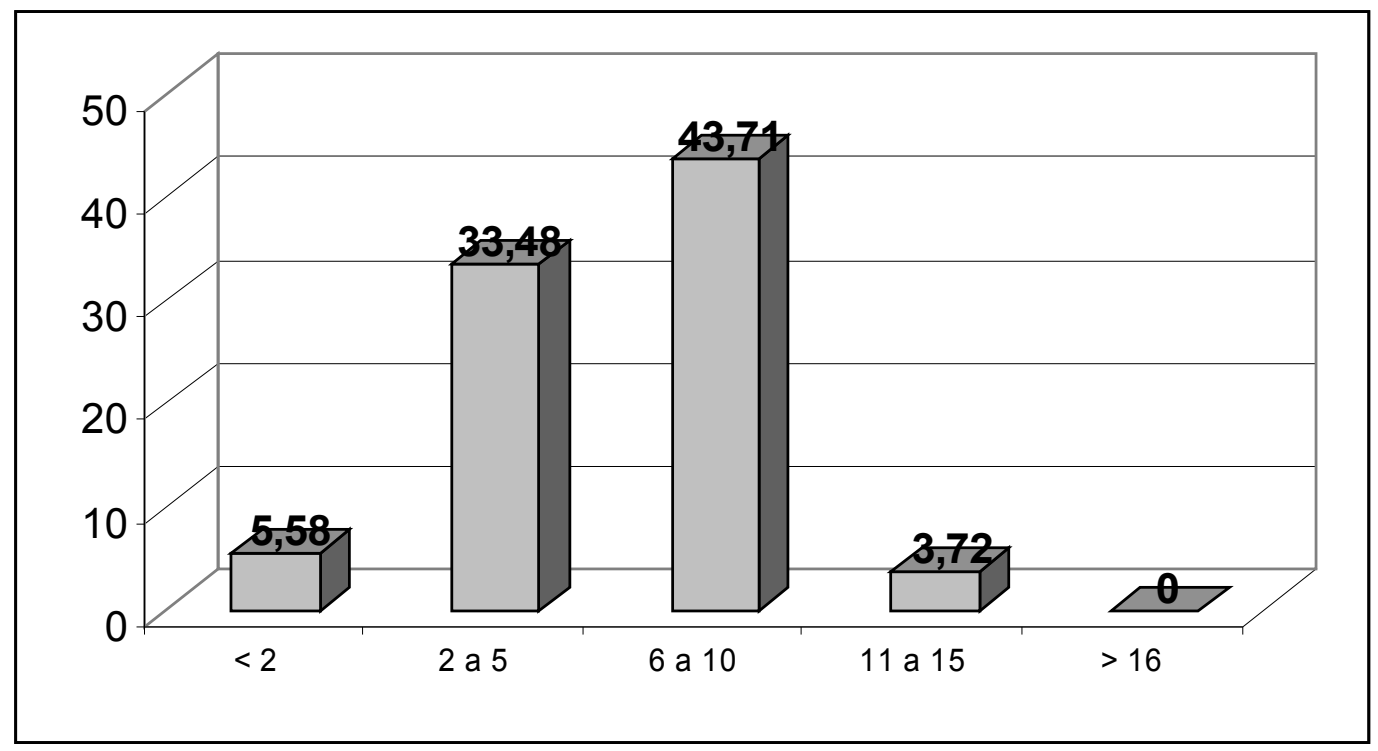

O rendimento mensal dos participantes da pesquisa foi respondido sem naturalidade por alguns, assumindo-se posturas de desvalorização ou supervalorização do seu provento. Observa-se $43,71 \%$ dos entrevistados informaram que o seu rendimento mensal é de até 10 salários mínimos.

Constata-se, pelos dados apresentados, uma estreita relação entre os rendimentos da população pesquisada e a sua situação profissional, pois $56 \%$ dos entrevistados trabalham (Gráfico 6), auferindo, assim, uma maior renda mensal. Percebe se que este segmento, em geral, possui tempo disponível e dinheiro para viajar, conforme Moletta (2000). 
Gráfico 8 - Residência

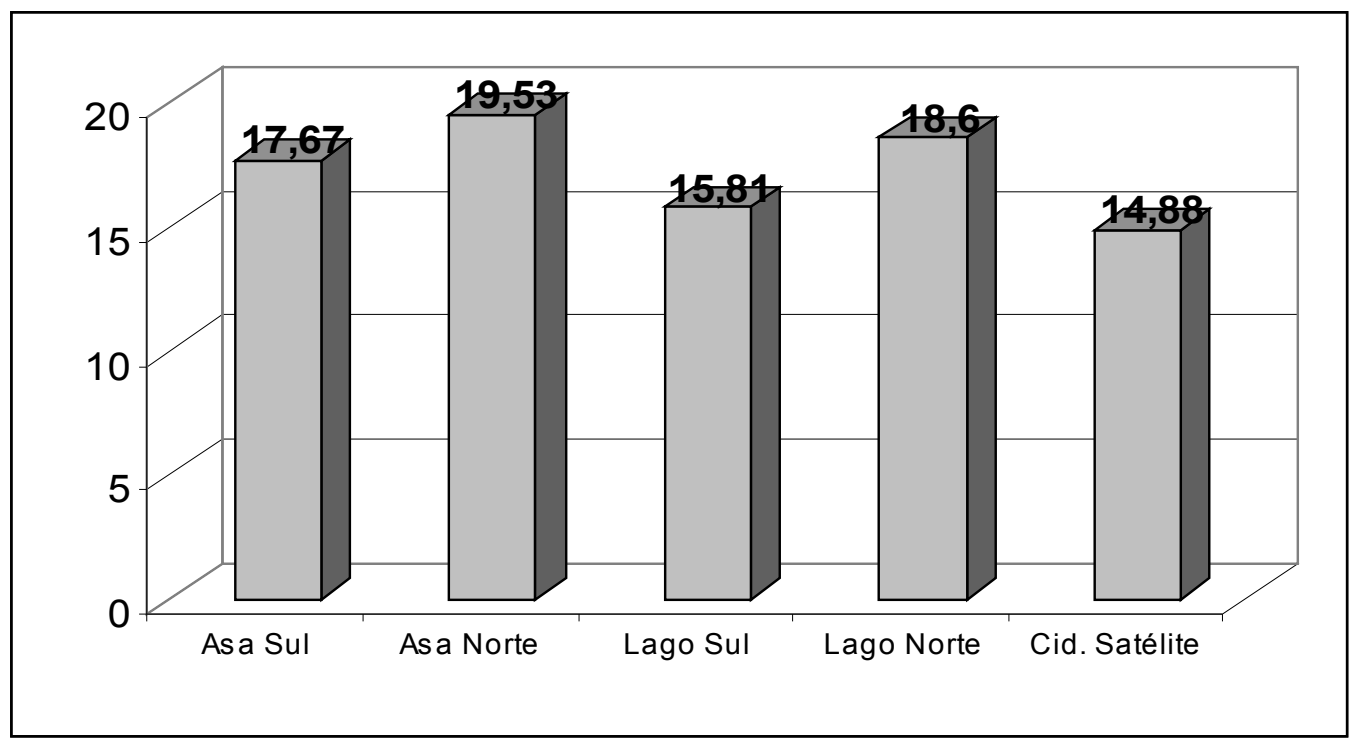

Através do Gráfico 8, pode-se perceber que a minoria dos respondentes vive nas cidades satélites (14,88\%) ou outros bairros citados, pertencentes a Brasília, e que são considerados locais de residência da classe média - 15,81\% no Lago Sul, $17,67 \%$ na Asa Sul, 18,6 no Lago Norte e 19, 53\% na Asa Norte.

Gráfico 9 - Moradia

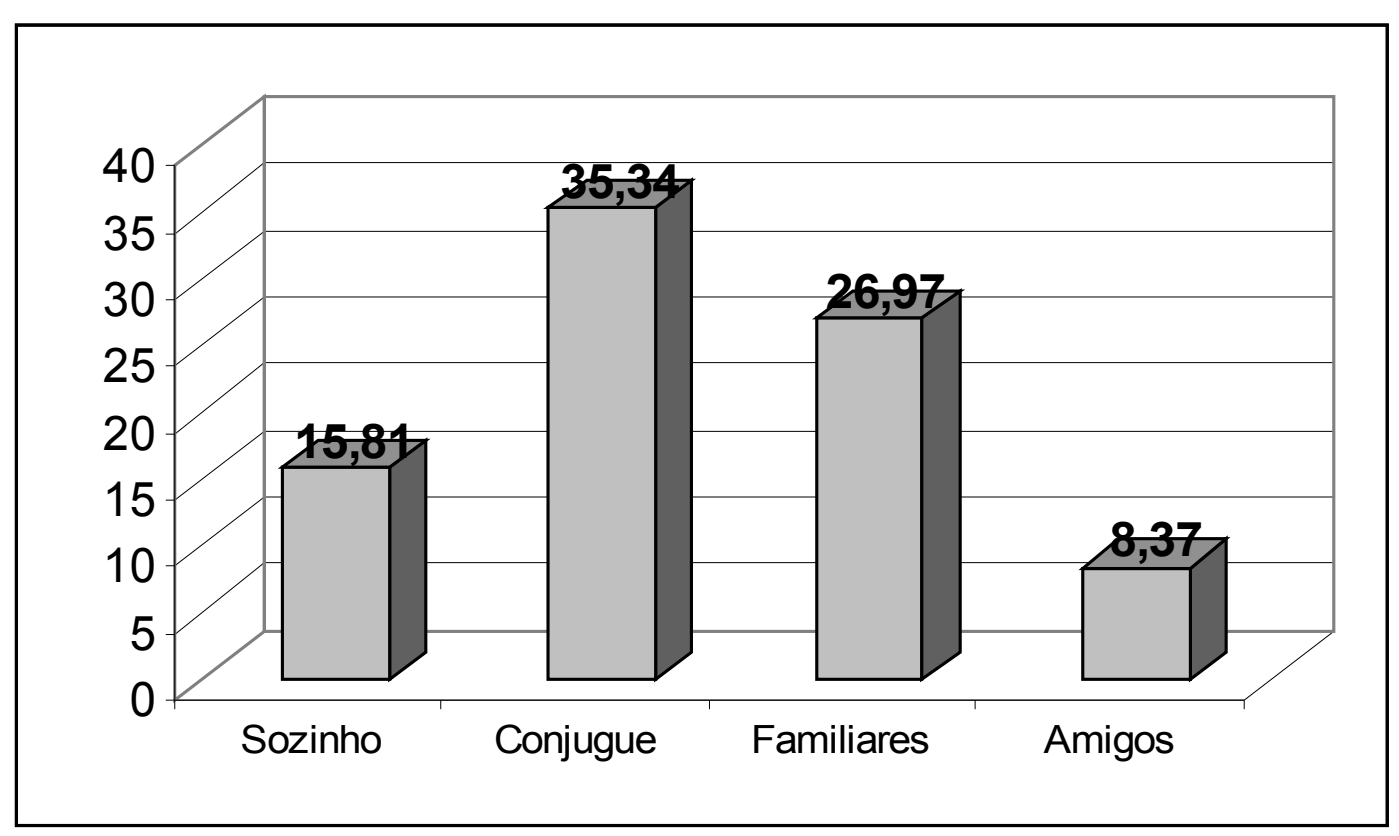

A maioria dos entrevistados $(35,34 \%)$ mora com o cônjuge. A questão é similar àquela analisada no gráfico 3 , onde revela-se que a maioria era casada. 
Gráfico 10 - Atividades que mais se identificam

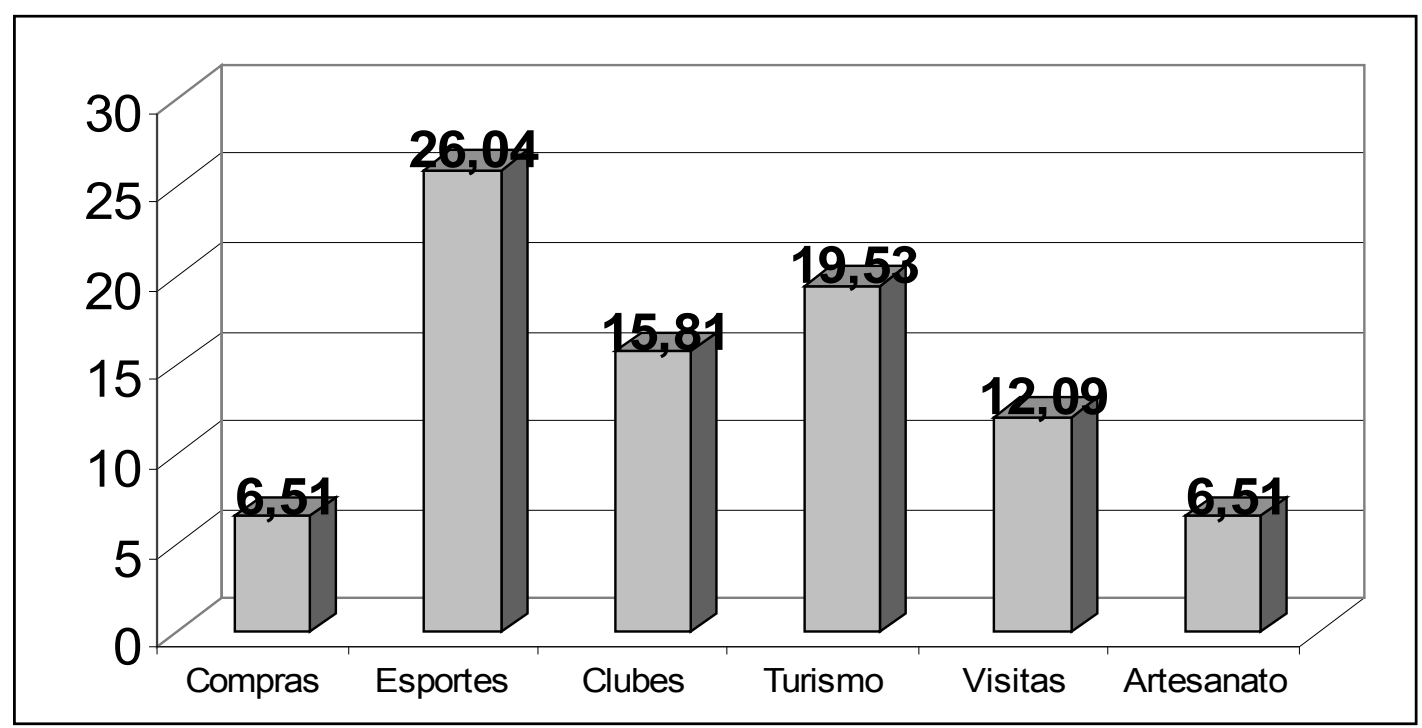

Verificando-se $\circ$ Gráfico 10 , pode-se observar qual atividade que o segmento da Terceira Idade mais se identifica na Capital Federal, mostrando-nos suas preferências em termos de eventos, lazer e entretenimento. Os locais de coleta desses dados foram parques - onde as pessoas praticam caminhadas e meditação e clubes para a Terceira Idade - freqüentados por aqueles que possuem o hábito de saírem constantemente de casa para interagirem com diversos grupos.

Gráfico 11 - Principais motivos para saírem de casa

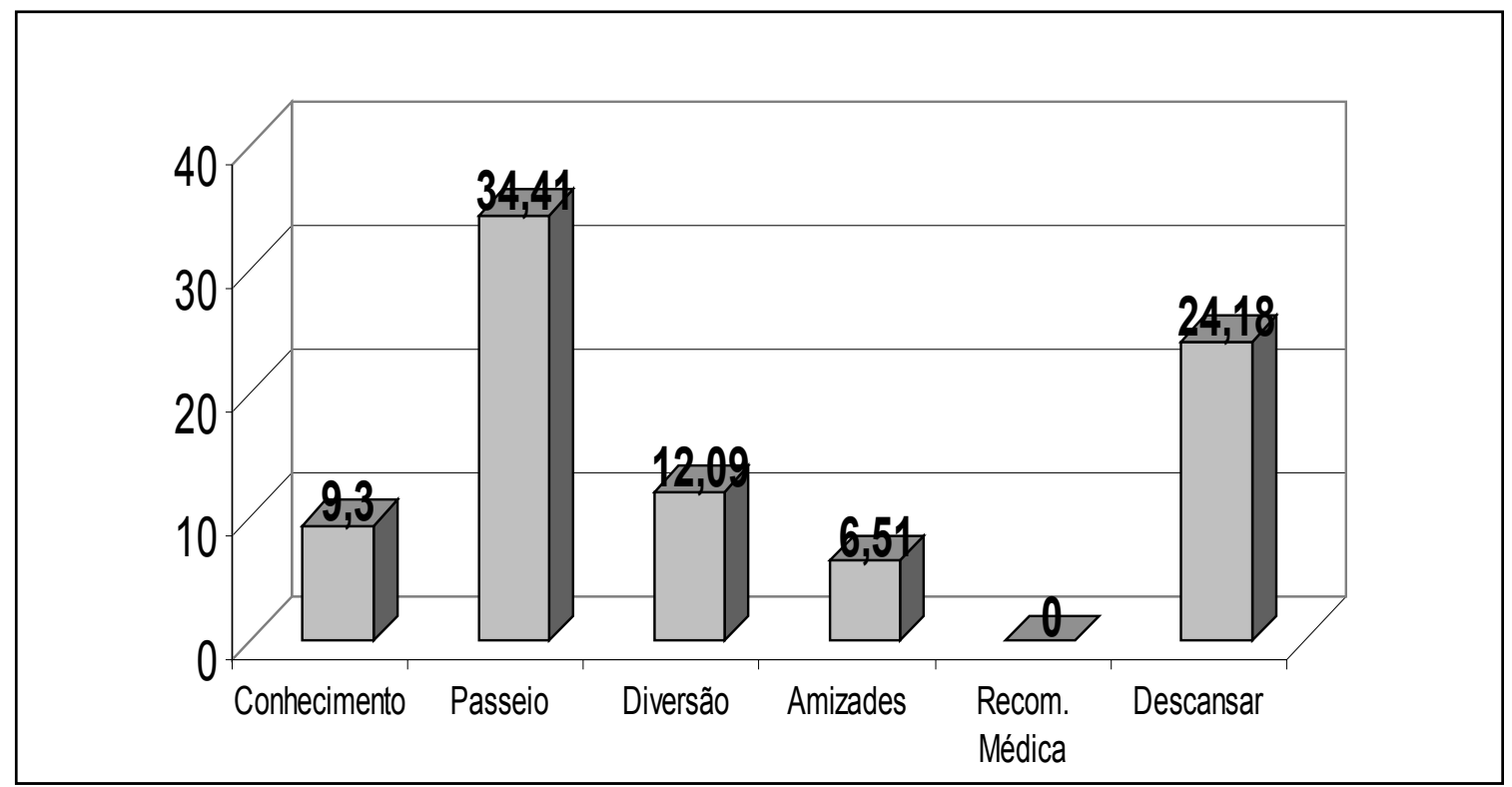

No Gráfico 11, aparecem os principais motivos dos entrevistados para saírem de casa, sendo o principal o passeio $(34,41 \%)$, seguido pelo descanso oferecido pela atividade $(24,18 \%)$. É de grande relevância para a Terceira Idade a 
prática de atividades culturais, lazer e esporte, pois elas permitem a socialização dos idosos.

Gráfico 12 - Lugares que costumam sair a lazer

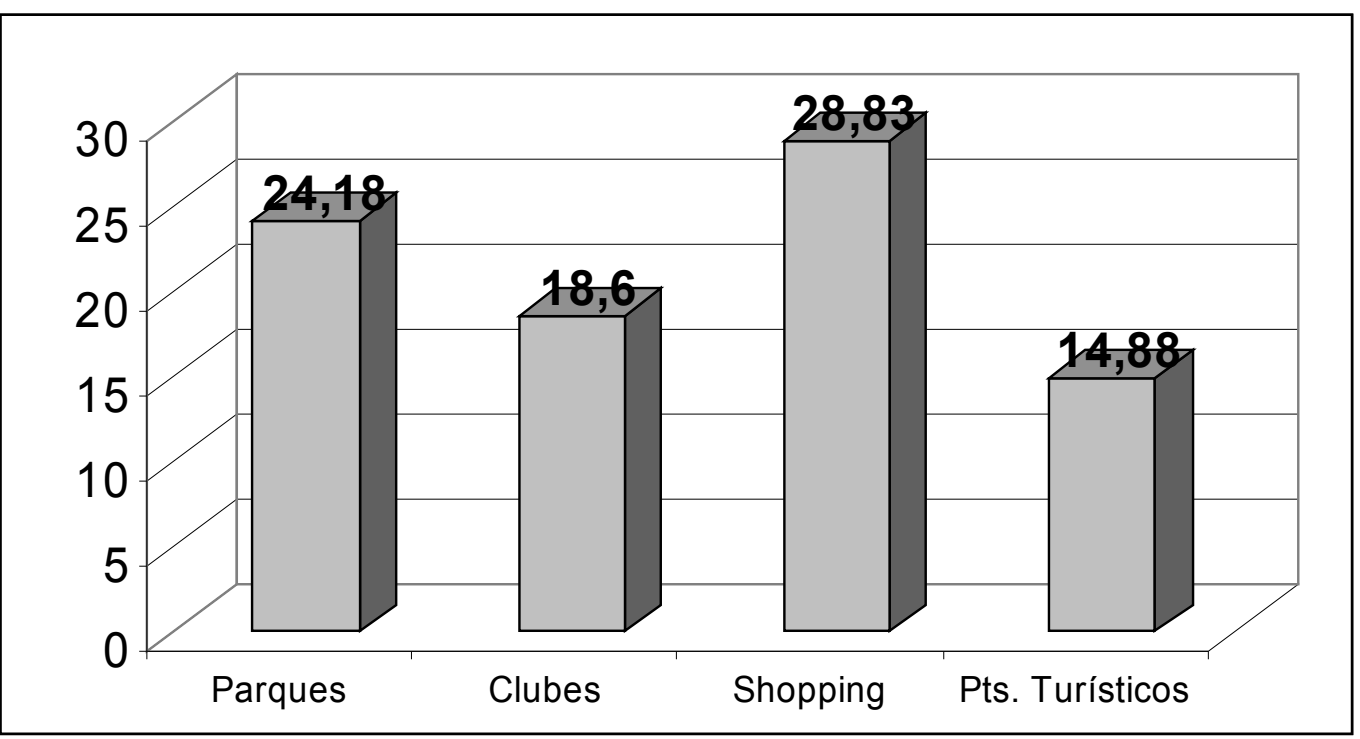

Os lugares de lazer mais freqüentados pelos idosos em Brasília são os shoppings $(28,83 \%)$, Parques $(24,18 \%)$ - é ali que geralmente praticam esportes, como vimos no Gráfico 10 -, os Clubes da Terceira Idade (18,6\%) e, por último, os Pontos turísticos $(14,88 \%)$.

Gráfico 13 - Tipos de programação que gostariam que existisse para melhorar/ aumentar, as opções de lazer e entretenimento em Brasília.

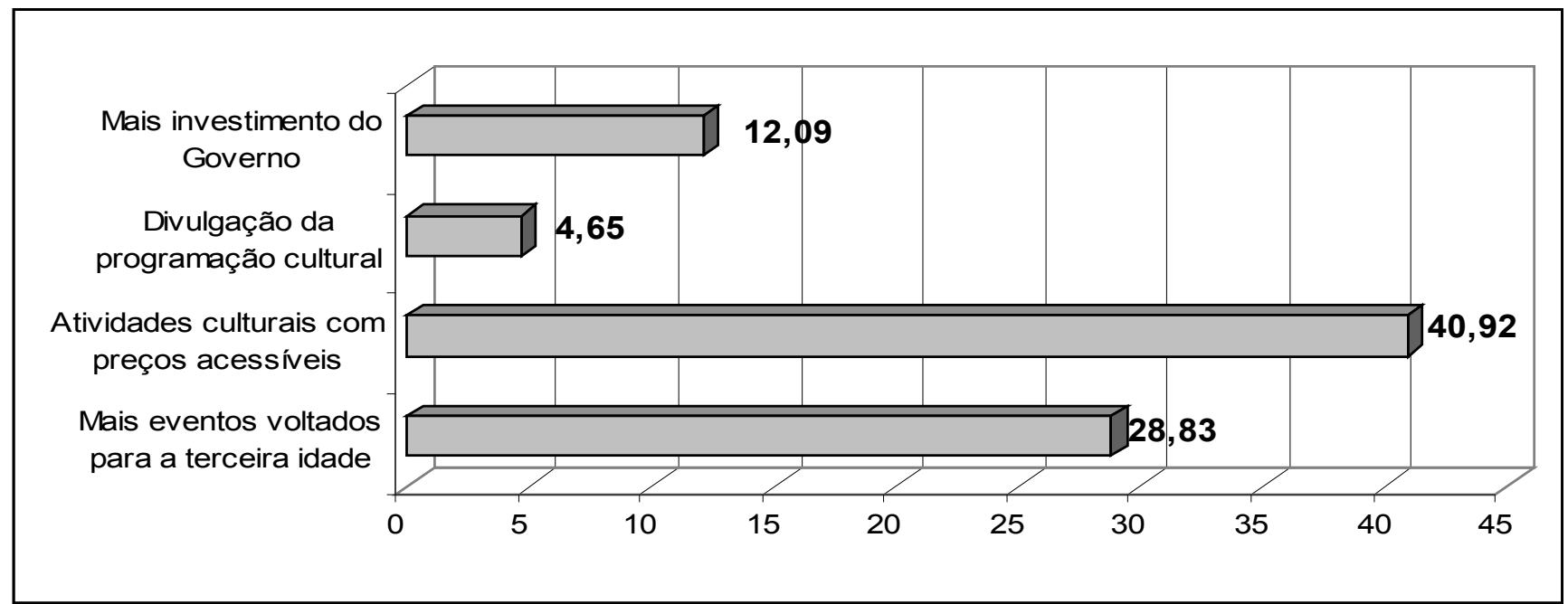

O Gráfico 13 apresenta o tipo de programação que os entrevistados gostariam que existisse para melhorar ou aumentar as opções de lazer e entretenimento no Distrito Federal. Nesta pergunta, colheram-se várias sugestões dos entrevistados, e apenas as quatro mais ressaltadas foram avaliadas. 
A maioria dos entrevistados $(40,92 \%)$ questionou os preços dos eventos e da programação cultural, justificando que são inacessíveis, o que impedem-nos de freqüentá-los. Em segundo lugar, 28,83\% desejaram que existissem mais eventos voltados à Terceira Idade, oferecidos pela Secretaria de Turismo do Distrito Federal.

Uma parcela de $12,09 \%$ sugeriu que o governo investisse mais nos eventos, nos lazeres e entretenimentos para o segmento estudado, enquanto $4,65 \%$ dos respondentes pediram uma divulgação mais especifica e intensa da programação cultural que Brasília oferece.

\subsubsection{Resultado da entrevista com o SESC}

O Serviço Social do Comércio do Distrito Federal desenvolve um trabalho com os idosos integrantes dos seus Grupos de Terceira Idade durante todo o ano. Os trabalhos acontecem mediante uma pesquisa de interesse com os participantes, de uma verificação dos recursos disponíveis, e de acordo com as datas festivas.

O SESC dispõe de uma equipe composta por assistentes sociais que coordenam todo o processo, bem como técnicos de outras áreas (lazer, saúde, esporte, cultura) responsáveis por realizar as atividades em conjunto com os outros profissionais do serviço social. As maiores exigências do SESC são a qualidade, a segurança e $o$ atendimento das necessidades e expectativas dos idosos.

Entrevistou-se a coordenadora da Ação Social e Terceira Idade do SESC, Regina Célia Aguieiros Caetano (Apêndice 1), a qual relatou que, nesta instituição, os eventos dividem-se em atividades culturais, educativas, sociais, artesanais, de lazer, físicas e assistência médica, e realizam-se reuniões semanais com programações variadas, de acordo com os temas propostos.

Além disso, desenvolvem-se programações externas ao SESC, tais como viagens e passeios organizados pelo turismo social do SESC. O trabalho que realizam durante o ano com os integrantes dos Grupos dos Mais Vividos do SESC acontece mediante a uma programação bimestral, que surge após uma pesquisa de 
interesse com os idosos, verificação de recursos disponíveis, e de acordo com as datas festivas. O SESC dispõe, ainda, de uma equipe composta por assistentes sociais que coordenam todo o processo, bem como técnicos de outras áreas (lazer, saúde, esporte, cultura) responsáveis por realizar as atividades juntamente com os estagiários de serviço social.

As exigências mais freqüentes para realizarem-se eventos voltados à Melhor Idade aliam-se às preocupações do SESC, que são a qualidade, a segurança e o atendimento das perspectivas/necessidades dos idosos, preocupando-se, também com a saúde do usuário, sua integridade moral e acidentes.

Em relação à alimentação, introduzem sempre uma dieta saudável e balanceada, e, quanto às adaptações, normalmente são indicadas pelos idosos as suas necessidades e, diante disso, tomam a providência conforme a possibilidade.

No Brasil, existem várias unidades de hospedagem do SESC com preço acessível, estrutura adequada e qualidade na prestação dos serviços, além da oferta de pacotes promocionais, bem como toda uma programação acompanhada por guias especializados em turismo e com o trato com os idosos.

Todas as unidades do SESC dispõem de estruturas adequadas para 0 trabalho desenvolvido, e, conforme as atividades, procura-se adaptar o espaço e as condições oferecidas, executando-as em um ambiente agradável.

A equipe técnica envolve profissionais de várias áreas - lazer, cultura, assistência, esporte, saúde, turismo -, todos com um perfil apropriado ao trabalho. Conforme o andamento das atividades, ela recebe orientações e acompanhamento do Serviço Social.

O SESC recebe propostas e convites de parcerias, mas o comum é este realizar os seus próprios eventos. Existe uma programação variada durante todo o ano, realizada nos 06 grupos existentes no Distrito Federal, em conjunto com os técnicos responsáveis pelo grupo de cada unidade, respeitando-se, porém, o perfil de cada grupo e de cada idoso, e, principalmente as opiniões e sugestões de atividades dos participantes. 


\subsubsection{Resultado da entrevista com o NEPTI}

O Núcleo de Estudos e Pesquisa da Terceira Idade da Universidade de Brasília atua principalmente com atividades voltadas para essa população, em conjunto com a sociedade. O projeto "O idoso em sua comunidade" tem sido um dos mais importantes desenvolvidos pelo núcleo, porque visa à participação do idoso na nossa sociedade. O NEPTI também realiza outros eventos com a colaboração da comunidade, juntamente com os coordenadores que compõem a equipe do projeto. Atualmente, existem mais de seiscentos idosos cadastrados, e são esses os mantenedores da comunidade.

A entrevista foi realizada com a Coordenadora do projeto "O Idoso em sua comunidade", Aldemita Portela Vaz de Oliveira. O NEPTI atua principalmente nas seguintes atividades: mini-cursos, coral, e no projeto acima mencionado. Os serviços mais oferecidos nessa instituição são palestras, encontros inter-geracionais, tardes de talentos, reuniões festivas, tarde culturais, debates, dinâmica de grupo e apresentações do coral. A coordenação do NEPTI conta com a colaboração da comunidade, que organizam os eventos.

As exigências mais freqüentes para realizarem-se eventos para a Terceira Idade são a disponibilidade de espaço físico e demanda da comunidade, e os cuidados necessários para organizá-los são a escolha de locais isentos de barreiras arquitetônicas, facilidade de acesso, e a adequação dos horários das atividades.

A maioria do público atendido pelo núcleo reside em Brasília, e os eventos mais procurados são cursos sobre temas atuais e de interesse geral, tais como meio ambiente, astronomia, saúde e psicologia, e, geralmente, são divulgados pela mídia.

Aqueles que trabalham com os eventos oferecidos pelo o NEPTI são pessoas da comunidade que realizam trabalhos voluntários, sendo o treinamento oferecido no próprio Núcleo de Estudos. 


\section{CONSIDERAÇÕES FINAIS}

O envelhecimento da população é inquestionável. Em 2050, de acordo com as projeções realizadas pela Organização das Nações Unidas (ONU), 22\% da população mundial, $22 \%$ da população da América Latina, e $23 \%$ da população brasileira terão sessenta anos ou mais. Esse fato originará a necessidade de um conjunto de alterações profundas em diferentes áreas - política, econômica, seguridade social, lazer, turismo, saúde, entre outras -, e exigirá que valores e comportamentos até então vigentes sejam revisitados, sobretudo a forma da velhice "ser vista" pela sociedade e do próprio velho "se ver".

Nesse contexto, o profissional do turismo deve atuar com uma ampla visão do processo do envelhecimento, tendo presente que envelhecer é uma experiência individual, e que produtos e serviços adequadamente definidos podem contribuir para que o idoso vivencie experiências gratificantes.

Tendo em vista esse cenário, a problemática deste estudo é pesquisar e analisar o mercado consumidor da Terceira Idade: seus hábitos de consumo, de lazer e de entretenimento em Brasília.

O objetivo geral é analisar os hábitos de lazer e entretenimento voltados para o segmento da Terceira Idade em Brasília. Os objetivos específicos foram os de identificar o perfil desse consumidor da Terceira Idade, e observar os seus hábitos de consumo, de lazer e de entretenimento.

Como resultado sintetizado, procurou-se traçar um perfil do segmento e do mercardo da Terceira Idade de Brasília. Assim, o respondente caracteriza-se por ser do sexo feminino, com faixa de idade entre 45 e 55 anos - cabendo destacar a presença de nove pessoas acima de setenta e cinco anos. Eles residem no Plano Piloto, são casados e vivem com o cônjuge. Possuem escolaridade de nível superior, estão profissionalmente ativos, e têm renda média de 6 a 10 salários mínimos.

Quanto aos hábitos de consumo, a maioria pratica esportes (26,04\%), sendo a diversão $(34,41 \%)$ um dos principais motivos para sairem de casa, seguida dos $24,18 \%$ que saem para aliviarem-se do estress e descansarem. Os idosos preferem 
sair principalmente para o shopping, ficando os parques em segundo lugar $(24,18 \%)$ - geralmente freqüentam-nos para a prática de esportes -, e os pontos turísticos em terceiro $(14,88 \%)$. Esse resultado enfatiza a idéia de que o progresso deste público deve ser estudado mais detalhadamente, fazendo com que as estratégias de mercado do turismo sejam melhor direcionadas e aplicadas, para contemplar e satisfazer essa parcela da população.

O segmento da Terceira Idade não é tratado com os devidos cuidados. Nota-se, nos dados coletados, que este público residente em Brasília possui uma demanda por lazer, entretenimento e eventos, pois há um aumento da população idosa, e esta possui um bom poder aquisitivo, tempo, e disposição para dar apreços a momentos de ócio.

O segundo objetivo especifico diz respeito ao levantamento das necessidades dos idosos, e o que eles gostariam que fosse-lhes oferecido em Brasília, em relação a eventos e lazer.

Observou-se que a maioria dos entrevistados (92\%) questionou os preços dos eventos e da programação cultural, justificando-se que estes não são tão acessíveis, impedindo-os de freqüentarem os locais de maior cultura. Sugeriu-se que fossem executados mais eventos e entretenimentos por parte da Secretaria de Turismo de Brasília, dando ênfase às necessidades desse segmento.

De acordo com os objetivos definidos, condicionantes do turismo para a Terceira Idade, procurou-se também buscar subsídios que possibilitassem uma melhor compreensão das associações e empresas específicas que trabalham com esse segmento, como por exemplo o SESC, o NEPTI, o Clube do Choro e o Parque da Cidade, entre outros.

Pode-se constatar que existem poucos eventos para a Terceira Idade em Brasília, sendo que, em sua maioria, são promovidos por essas associações e empresas já citadas. A realização desses encontros ocorre nos próprios locais (SESC, NEPTI, etc), e as atividades são diversificadas, tais como caminhadas, festas, bingos, palestras e outros. O Gráfico 13 demonstra esses dados, quando percebe-se o tipo de programação que os idosos entrevistados gostariam que houvesse para aumentar as suas opções de entretenimento, fora dos lugares costumeiros. 
De modo geral, essas empresas e associações têm criado novas oportunidades de integração, participação e vivência dos idosos na sociedade, com as suas atividades de lazer e eventos, permitindo ao idoso vencer certos obstáculos, estimulando seu desenvolvimento físico e mental.

Os dados analisados, de acordo com as categorias acima comentadas, garantem que os objetivos estabelecidos para esta pesquisa foram alcançados em parte, e que, possivelmente, agregarão valor ao campo do conhecimento relacionado.

Acredita-se que, para o adequado desenvolvimento do turismo para a Terceira Idade, além de se considerar o envelhecimento como um processo individual, também é importante a observância de algumas constatações relativas às pessoas, aos locais, às necessidades e às estruturas que compõem esse segmento. Cabe, então, destacarem-se algumas propostas e sugestões para enriquecer os seguintes aspectos:

- Em primeiro lugar, um estudo mais aperfeiçoado e abrangente sobre hábitos de consumo de lazer, eventos e entretenimento, evitando-se tratar este segmento como único, e, sim, como constituído por vários subgrupos de preferências diversificadas;

- Pesquisar locais para a realização de algumas tarefas (como eventos e lazer), atendendo às expectativas do grupo a ser trabalhado;

- Fazer uma análise das necessidades e demandas dos idosos, prezando a segurança - em relação às adaptações nos locais mais freqüentados -, a alimentação e a saúde, sendo necessária a presença de um profissional de saúde para se evitar surpresas desagradáveis.

Em síntese, a Terceira Idade é um segmento que cresce cada vez mais, e demonstra que vale a pena ser explorado, portanto, merece mais atenção dos empreendedores do ramo de lazer e entretenimento. Futuramente, se bem trabalhado, este segmento poderá gerar grande retorno para o turismo da cidade e de todo o trade turístico. Naturalmente, o público da Terceira Idade passará a ter mais opções de entretenimento. 
Considera-se Brasília uma cidade com um grande potencial turístico, e com possibilidades de viabilizar eventos para a Terceira Idade. Assim, este estudo comprova que o público nas faixas etárias de 45 a 65 anos deseja atividades culturais e sociais, e que, havendo a oferta, ele consumirá. 


\section{REFERÊNCIAS BIBLIOGRÁFICAS}

ACERENZA, Miguel A. Administração do turismo. Bauru: EDUSC, 2002.

ANDRADE, José Vicente de. Turismo: fundamentos e dimensões. 7 ed. São Paulo: Ed. Ática, 2002.

AREAL, Augusto César B. A História de Brasília. 2003. Disponível em: <http://www.infobrasilia.com.br/bsb_h1p.htm> Acesso em: 06 de fevereiro de 2007.

BACAL, Sarah. Lazer e o universo dos possíveis. São Paulo: Aleph, 2003.

BALDESSIN, A . O idoso: viver e morrer com dignidade. In: Papaléo Netto, Matheus (coord.) Gerentologia: a velhice e o envelhecimento em visão globalizada. São Paulo: Atheneu, 1999.

BARBETTA, Pedro Alberto. Estatísticas aplicada às Ciências Sociais. Florianópolis: UFSC, 2000.

BEAUVOIR, Simone de. A velhice. Trad. Maria Helena Franco Martins. Rio de Janeiro: Nova Fronteira, 1990.

BENI, Mario C. Análise estrutural do turismo. 2 ed. São Paulo, editora SENAC, 1998.

CHIZZOTTI, A. Pesquisa em ciências humanas e sociais. 4. ed. São Paulo: Cortez, 2000. 
CHURCHILL, Gilbert. Marketing research: methodological foundations. 2a ed. The Dryden Press. 1998.

DEBERT, G. G. A . Antropología e o estudo dos grupos e das categorías de idade. In: BARROS, M. M. L. de B. (Org.). Velhice ou Terceira Idade. Rio de Janeiro: Ed. Da FGV, 1998.

DE LA TORRE, Oscar. El turismo: fenómeno social. 2 ed. México. Ed. Fundo da Cultura Economica, 1997.

DIAS, Reinaldo. Fundamentos do marketing turístico.São Paulo: Pearson Prentice Hall, 2005.

EMBRATUR. Estudos do Turismo Brasileiro. São Paulo: Terragraf, 1998.

FERRARI, Maria Auxiliadoras Cursino. Lazer e ocupação do tempo livre na Terceira Idade. In: Papaléo Netto, Matheus (coord.) Gerentologia: a velhice e o envelhecimento em visão globalizada. São Paulo: Atheneu, 1999.

FROMER, Betty, VIEIRA, Débora. Turismo e Terceira idade.São Paulo: Editora Aleph, 2003. Coleção ABC do turismo.

GARCIA, Maria Teresa Gonçalves. Turismo na Terceira Idade: um mercado em potencial. 2001. 281 f. Tese (Doutorado em Ciências Da Comunicação) - Escola de Comunicações e Artes, Universidade de São Paulo, São Paulo.

GIACAGLIA, Maria C. Organização de Eventos. Teoria e Prática. São Paulo: Afiliada, 2003. 
GIL, Antônio Carlos. Como elaborar projetos de pesquisa. São Paulo: Atlas, 2002.

GOLDSTEIN, L. E por falar em boa velhice. Campinas: Papirus, 2004

INSTITUTO BRASILEIRO DE GEOGRAFIA E ESTATÍSTICA. Censo demográfico 2006: resultados do universo. Disponível em: http://www.ibge.go.br. Acesso em 21 de fevereiro de 2007.

KINNEAR, Thomas C. \& TAYLOR, James R. Marketing research: an applied aproach. Mc Graw Hill. 1979.

KOTLER, Phiplip. Administração de marketing: a edição do novo milênio. Tradução de Bazán Tecnoligia e Lingüística. 10. ed. São Paulo: Prentice Hall, 2000.

Do marketing móvel às lacunas de valor. Revita HSM, n. 28, ano 5, p. 116- 120, nov./dez. 2001. São Paulo: HSM do Brasil, 2001. ISSN 14158868.

MATIAS, Marlene. Organização de eventos. Procedimentos e técnicas. São Paulo: Editora Manole, 2001.

MEIRELLES, Gilda F. Tudo sobre eventos. São Paulo: STS, 1999.

MOLETTA, Vânia Florentino. Turismo para a Terceira Idade. Porto Alegre: SEBRAE/RS, 2000.

MONTEIRO, Érica. FEITOSA, Valéria. Disponível em: http://www.correioweb.com.br, acesso em 27 de outubro de 2006. 
NEVES, Regina. A comunicação volta seu foco aos maiores de 60 anos. Jornal Gazeta Mercantil. 29 março, 2004, Caderno Mídia \& Marketing, p. A-38

NOVAES, M.H. Psicologia da Terceira idade. Conquistas possíveis e rupturas necessárias. Rio de janeiro: Nau Editora, 1995.

OLIVEIRA, Antônio Pereira. Turismo e desenvolvimento - Planejamento e Organização 3 ed. São Paulo Editora Atlas,2001.

ORGANIZAÇÃO MUNDIAL DO TURISMO. Turismo internacional: uma perspectiva global. 2. ed. Porto Alegre: Bookmann, 2003.

PALMA, L. T. S. A. Educação permanente e qualidade de vida: indicativos para uma velhice bem sucedida. Passo Fundo, RS: UPF, 2000.

PASCHOAL, S. M. P. Epidemoligia do envelhecimento. São Paulo: Atheneu. 2000.

PRESSER, Nadi Helena. In Modelo de configuração organizacional para uma instituição de idosos - SC. Dissertação defendida para obtenção do título de doutor em Engelharia de Produção. Santa Catarina, 2005.

RICHERS, Raimar e lima Cecília Pimenta - Segmentação. São Paulo Nobel 1991.

RUSCHMANN, Doris. Turismo e planejamento sustentável: A proteção do meio ambiente. Campinas: Papirus, 1997.

SCHIFFMAN, L. \& KANUK, L. Comportamento do consumidor. LTC Editora. $6^{\text {a }}$ ed. 2000. 
SPÉZIA, Domingos Sávio. In: Metodologia da pesquisa. Apostila utilizada para ministrar a disciplina de Metodologia da Pesquisa para o Curso de Gestão de Negócios em Turismo II. Brasília: UNB, 2006.

UNITED NATIONS. POPULATION Division. Department of Economics an Social Affairs. Population agein 2000. Disponível em: http://www.undp.or Acessado em 28 de fevereiro de 2007.

VERA, Armando Asti. Metodologia da pesquisa científica. Porto Alegre: Globo, 2005.

WORLD TOURISM ORGANIZATION (WTO). International conference on senior tourism (2,1996: Recife/Olinda) Proceedings-selected materals. Madri: WTO, 1997. 


\section{APÊNDICE A - Entrevista com o SESC}

\section{EVENTOS PARA SEGMENTO DA TERCEIRA IDADE NO DISTRITO FEDERAL}

IDENTIFICAÇÃO DA INSTITUIÇÃO: Serviço Social do Comércio - Administração ENTREVISTADO: Regina Célia Aguieiros Caetano

CARGO: Coordenação de Ação Social e Terceira Idade

1) Qual (ais) é (são) o(s) tipo(s) de evento(s) mais comum (uns) realizado(s) para o público da Terceira Idade em Brasília?

No SESC, os eventos dividem-se entre atividades culturais, educativas, sociais, artesanais, de lazer, físicas e assistência médica.

\section{2) Que serviços mais habituais são oferecidos nesses eventos?}

São realizadas reuniões semanais com programações variadas de acordo com os temas já supracitados. Além disso, desenvolvemos programações externas ao SESC, tais como as viagens e passeios organizados pelo turismo social do SESC.

\section{3) Quem organiza esses eventos para a terceira Idade?}

O trabalho a ser desenvolvido durante o ano com os idosos integrantes dos Grupos dos Mais Vividos do SESC, acontece mediante programação bimestral que surge mediante pesquisa de interesse dos idosos, recursos disponíveis e de acordo com as datas festivas. O SESC dispõe de equipe composta por assistentes sociais que coordenam todo o processo, bem como técnicos de outras áreas (lazer, saúde, esporte, cultura) responsáveis em realizar as atividades juntamente com os estagiários de serviço social.

4) Quais são as exigências mais freqüentes para se realizar eventos para a terceira Idade?

A maior exigência que o SESC se preocupa é com a qualidade, segurança e que, se atenda as perspectivas/ necessidades dos idosos.

5) Quais os cuidados que se deve ter ao se organizar eventos para a Terceira Idade?

Normalmente, nos preocupamos com a saúde do idoso, integridade moral e acidentes.

6) Que tipo de meios de hospedagem costumam atender a esse público no Distrito federal?

No Brasil inteiro existem Unidades de Hospedagem do SESC com preço acessível, estrutura adequada e qualidade na prestação dos serviços. Acrescentamos a isso, 
pacotes promocionais, bem como toda uma programação acompanhada por guia especializado em turismo e com o trato com idosos.

7) Em se tratando de eventos, quais os tipos mais demandados por esse público na região?

Passeios e festas.

8) Quais os locais mais apropriados, adaptados e preparados para a realização de eventos para a Terceira Idade em Brasília?

Todas as Unidades do SESC dispõem de estrutura adequada para o trabalho desenvolvido e, conforme a atividade, procuramos adaptar o espaço e condições oferecidas. Em relação às atividades, procuramos na maioria das vezes proporcionar ambiente arejado e próximo à natureza.

9) Como é feito o recrutamento e treinamento das pessoas que trabalham nesses eventos?

A equipe técnica envolve profissionais de várias áreas - lazer, cultura, assistência, esporte, saúde, turismo -, com perfil apropriado ao trabalho. Estes, conforme o andamento das atividades recebem orientações e acompanhamento do Serviço Social.

\section{0) Como funciona a captação desses eventos para a Terceira Idade?}

O SESC recebe propostas de parcerias e convites, mas o comum é este realizar os seus próprios eventos. Durante todo o ano existe programação variada realizada nos 06 grupos existentes no SESC/ DF. A programação é realizada em conjunto com os técnicos responsáveis pelo grupo de cada Unidade, lembrando-se sempre, no respeito pelo perfil de cada grupo/idoso e principalmente na opinião e sugestões de atividades dos idosos. 


\section{APÊNDICE B - Entrevista com o NEPTI}

\section{EVENTOS PARA SEGMENTO DA TERCEIRA IDADE NO DISTRITO FEDERAL}

IDENTIFICAÇÃO DA INSTITUIÇÃO: NEPTI/ CEAM UnB

ENTREVISTADO: Aldemita Portela Vaz de Oliveira

CARGO: Coordenadora do projeto "O Idoso em sua Comunidade".

1) Qual (ais) é (são) o(s) tipo(s) de evento(s) mais comum (uns) realizado(s) para o público da Terceira Idade em Brasília?

O NEPTI atua principalmente nas seguintes atividades: mini-cursos, coral e no projeto "O Idoso em sua Comunidade".

2) Que serviços mais habituais são oferecidos nesses eventos?

Palestras, encontros inter-geracionais, tardes de talentos, reuniões festivas, tarde cultural, debates dinâmica de grupo, apresentação do coral.

3) Quem organiza esses eventos para a terceira Idade?

A coordenação do NEPTI, com a colaboração da comunidade.

4) Quais são as exigências mais freqüentes para se realizar eventos para a terceira Idade?

Disponibilidade de espaço físico e demanda da comunidade.

5) Quais os cuidados que se deve ter ao se organizar eventos para a Terceira Idade?

Local isento de barreiras arquitetônicas, de fácil acesso e realização das atividades em horário adequado ao público-alvo.

6) Que tipo de meios de hospedagem costumam atender a esse público no Distrito federal?

O NEPTI serve um lanche leve.

7) Em se tratando de eventos, quais os tipos mais demandados por esse público na região?

Cursos sobre temas atuais e de interesse geral, tais como: meio ambiente, astronomia, saúde, psicologia. 
8) Quais os locais mais apropriados, adaptados e preparados para a realização de eventos para a Terceira Idade em Brasília?

As salas de aula e auditórios da UnB .

9) Como é feito o recrutamento e treinamento das pessoas que trabalham nesses eventos?

O NEPTI convida pessoas da comunidade para realizar trabalhos voluntários. O treinamento é oferecido no próprio Núcleo de Estudos.

10) Como funciona a captação desses eventos para a Terceira Idade?

Pela mídia, jornais, rádio e televisão. Com mais de 10 anos de atividades o NEPTI já possui mais de 600 idosos cadastrados em sua mala direta. 


\section{APÊNDICE C - Questionário - quantitativo}

1-Gênero: ( ) Feminino （）Masculino

\section{2-Há quanto tempo reside em Brasília?}

( ) Menos de 5 anos （）De 5 a 10 anos （） De 11 a 15 anos （） De 16 a 20anos ( ) Mais de 20 anos

3-Estado civil:

( ) Solteiro(a) ( )Casado (a) ( ) Viúvo (a) ( ) Desquitado (a)

4-Faixa etária:

( ) de 45 a 55 anos ( ) de 56 a 65 anos

( ) de 66 a 75 anos ( ) acima de 75

5- Escolaridade:

( ) $1^{\circ}$. Grau incompleto ( ) $1^{\circ}$. Grau completo ( ) $2^{\circ}$. Grau incompleto

( ) $2^{\circ}$. Grau completo ( ) Superior Incompleto ( ) Superior Completo

6-Situação profissional:

( ) Trabalhando ( ) Aposentado (a) e não trabalha

( ) Aposentado (a) em atividade ( ) Pensionista ( ) outros

7-Rendimento mensal:

( ) menos de 2 salários mínimos （） de 2 a 5 salários mínimos

( ) de 6 a 10 salários mínimos ( ) de 11 a 15 salários mínimos

( ) de 16 a 20 salários mínimos 
8-Onde mora:

( ) Asa sul ( ) Asa norte ( ) Lago sul ( ) Lago norte

( ) Cidade Satélite

10-Mora:

( ) Sozinho ( ) Cônjugue ( ) Familiares ( ) amigos

11-Quanto à atividade que mais se identifica. (máximo 3):

( ) Ida a centros de compras ( ) Prática de esportes ( ) Visita a museus

( ) exposições ( ) cinema ( ) teatro ( ) clubes ( )Turismo

( ) Dança ( )canto ( )literatura

( )jogos ( ) Visita a amigos/ familiares ( ) Atividades manuais- artesanato

12-Quais os principais motivos para sair de casa:

( ) Para enriquecer seus conhecimentos （）Passeio （）diversão （）para fazer novas amizades ( ) Por recomendação médica ( ) Para aliviar do estress, descansar

13-Quais os lugares que costuma sair, quando vai fazer lazer:

( ) Parques, zoológico, lago （）Clubes para melhor idade （）Shopping ( ) Pontos turísticos da cidade

14-Que tipo de programação que gostaria que existisse para melhorar/ aumentar, opções de lazer e entretenimento no Distrito Federal? 


\section{ANEXO A- Estatuto do Idoso}

\section{LEI № 10.741, DE 1 DE OUTUBRO DE 2003.}

Dispõe sobre o Estatuto do Idoso e dá outras providências.

O PRESIDENTE DA REPÚBLICA Faço saber que o Congresso Nacional decreta e eu sanciono a seguinte Lei:

TÍTULO I

Disposições Preliminares

Art. $1^{\circ}$ É instituído o Estatuto do Idoso, destinado a regular os direitos assegurados às pessoas com idade igual ou superior a 60 (sessenta) anos.

Art. $2^{\circ} \mathrm{O}$ idoso goza de todos os direitos fundamentais inerentes à pessoa humana, sem prejuízo da proteção integral de que trata esta Lei, assegurando-seIhe, por lei ou por outros meios, todas as oportunidades e facilidades, para preservação de sua saúde física e mental e seu aperfeiçoamento moral, intelectual, espiritual e social, em condições de liberdade e dignidade.

Art. $3^{\circ}$ É obrigação da família, da comunidade, da sociedade e do Poder Público assegurar ao idoso, com absoluta prioridade, a efetivação do direito à vida, à saúde, à alimentação, à educação, à cultura, ao esporte, ao lazer, ao trabalho, à cidadania, à liberdade, à dignidade, ao respeito e à convivência familiar e comunitária.

Parágrafo único. A garantia de prioridade compreende:

I - atendimento preferencial imediato e individualizado junto aos órgãos públicos e privados prestadores de serviços à população;

II - preferência na formulação e na execução de políticas sociais públicas específicas;

III - destinação privilegiada de recursos públicos nas áreas relacionadas com a proteção ao idoso;

IV - viabilização de formas alternativas de participação, ocupação e convívio do idoso com as demais gerações;

V - priorização do atendimento do idoso por sua própria família, em detrimento do atendimento asilar, exceto dos que não a possuam ou careçam de condições de manutenção da própria sobrevivência; 
VI - capacitação e reciclagem dos recursos humanos nas áreas de geriatria e gerontologia e na prestação de serviços aos idosos;

VII - estabelecimento de mecanismos que favoreçam a divulgação de informações de caráter educativo sobre os aspectos biopsicossociais de envelhecimento; locais.

VIII - garantia de acesso à rede de serviços de saúde e de assistência social

Art. $4^{\circ}$ Nenhum idoso será objeto de qualquer tipo de negligência, discriminação, violência, crueldade ou opressão, e todo atentado aos seus direitos, por ação ou omissão, será punido na forma da lei.

$\S 1^{\circ}$ É dever de todos prevenir a ameaça ou violação aos direitos do idoso.

$\S 2^{\circ}$ As obrigações previstas nesta Lei não excluem da prevenção outras decorrentes dos princípios por ela adotados.

Art. $5^{\circ}$ A inobservância das normas de prevenção importará em responsabilidade à pessoa física ou jurídica nos termos da lei.

Art. $6^{\circ}$ Todo cidadão tem o dever de comunicar à autoridade competente qualquer forma de violação a esta Lei que tenha testemunhado ou de que tenha conhecimento.

Art. $7^{\circ}$ Os Conselhos Nacional, Estaduais, do Distrito Federal e Municipais do Idoso, previstos na Lei $n^{\circ} 8.842$, de 4 de janeiro de 1994, zelarão pelo cumprimento dos direitos do idoso, definidos nesta Lei.

TÍTULO ॥

Dos Direitos Fundamentais

CAPÍTULO I

Do Direito à Vida

Art. $8^{\circ} \mathrm{O}$ envelhecimento é um direito personalíssimo e a sua proteção um direito social, nos termos desta Lei e da legislação vigente.

Art. $9^{\circ}$ É obrigação do Estado, garantir à pessoa idosa a proteção à vida e à saúde, mediante efetivação de políticas sociais públicas que permitam um envelhecimento saudável e em condições de dignidade.

CAPÍTULO II

Do Direito à Liberdade, ao Respeito e à Dignidade 
Art. 10. É obrigação do Estado e da sociedade, assegurar à pessoa idosa a liberdade, o respeito e a dignidade, como pessoa humana e sujeito de direitos civis, políticos, individuais e sociais, garantidos na Constituição e nas leis.

$\S 1^{\circ} \mathrm{O}$ direito à liberdade compreende, entre outros, os seguintes aspectos:

I - faculdade de ir, vir e estar nos logradouros públicos e espaços comunitários, ressalvadas as restrições legais;

II - opinião e expressão;

III - crença e culto religioso;

IV - prática de esportes e de diversões;

V - participação na vida familiar e comunitária;

VI - participação na vida política, na forma da lei;

VII - faculdade de buscar refúgio, auxílio e orientação.

$\S 2^{\circ} \mathrm{O}$ direito ao respeito consiste na inviolabilidade da integridade física, psíquica e moral, abrangendo a preservação da imagem, da identidade, da autonomia, de valores, idéias e crenças, dos espaços e dos objetos pessoais.

$\S 3^{\circ}$ É dever de todos zelar pela dignidade do idoso, colocando-o a salvo de qualquer tratamento desumano, violento, aterrorizante, vexatório ou constrangedor.

\section{CAPÍTULO III}

Dos Alimentos

Art. 11. Os alimentos serão prestados ao idoso na forma da lei civil.

Art. 12. A obrigação alimentar é solidária, podendo o idoso optar entre os prestadores.

Art. 13. As transações relativas a alimentos poderão ser celebradas perante o Promotor de Justiça, que as referendará, e passarão a ter efeito de título executivo extrajudicial nos termos da lei processual civil.

Art. 14. Se o idoso ou seus familiares não possuírem condições econômicas de prover o seu sustento, impõe-se ao Poder Público esse provimento, no âmbito da assistência social.

CAPÍTULO IV

Do Direito à Saúde 
Art. 15. É assegurada a atenção integral à saúde do idoso, por intermédio do Sistema Único de Saúde - SUS, garantindo-lhe o acesso universal e igualitário, em conjunto articulado e contínuo das ações e serviços, para a prevenção, promoção, proteção e recuperação da saúde, incluindo a atenção especial às doenças que afetam preferencialmente os idosos. de:

$\S 1^{\circ} \mathrm{A}$ prevenção e a manutenção da saúde do idoso serão efetivadas por meio

I - cadastramento da população idosa em base territorial;

II - atendimento geriátrico e gerontológico em ambulatórios;

III - unidades geriátricas de referência, com pessoal especializado nas áreas de geriatria e gerontologia social;

IV - atendimento domiciliar, incluindo a internação, para a população que dele necessitar e esteja impossibilitada de se locomover, inclusive para idosos abrigados e acolhidos por instituições públicas, filantrópicas ou sem fins lucrativos e eventualmente conveniadas com o Poder Público, nos meios urbano e rural;

V - reabilitação orientada pela geriatria e gerontologia, para redução das seqüelas decorrentes do agravo da saúde.

$\S 2^{\circ}$ Incumbe ao Poder Público fornecer aos idosos, gratuitamente, medicamentos, especialmente os de uso continuado, assim como próteses, órteses e outros recursos relativos ao tratamento, habilitação ou reabilitação.

$\S 3^{\circ}$ É vedada a discriminação do idoso nos planos de saúde pela cobrança de valores diferenciados em razão da idade.

$\S 4^{\circ}$ Os idosos portadores de deficiência ou com limitação incapacitante terão atendimento especializado, nos termos da lei.

Art. 16. Ao idoso internado ou em observação é assegurado o direito a acompanhante, devendo o órgão de saúde proporcionar as condições adequadas para a sua permanência em tempo integral, segundo o critério médico.

Parágrafo único. Caberá ao profissional de saúde responsável pelo tratamento conceder autorização para o acompanhamento do idoso ou, no caso de impossibilidade, justificá-la por escrito.

Art. 17. Ao idoso que esteja no domínio de suas faculdades mentais é assegurado o direito de optar pelo tratamento de saúde que lhe for reputado mais favorável.

Parágrafo único. Não estando o idoso em condições de proceder à opção, esta será feita:

I - pelo curador, quando o idoso for interditado; 
II - pelos familiares, quando o idoso não tiver curador ou este não puder ser contactado em tempo hábil;

III - pelo médico, quando ocorrer iminente risco de vida e não houver tempo hábil para consulta a curador ou familiar;

IV - pelo próprio médico, quando não houver curador ou familiar conhecido, caso em que deverá comunicar o fato ao Ministério Público.

Art. 18. As instituições de saúde devem atender aos critérios mínimos para o atendimento às necessidades do idoso, promovendo o treinamento e a capacitação dos profissionais, assim como orientação a cuidadores familiares e grupos de autoajuda.

Art. 19. Os casos de suspeita ou confirmação de maus-tratos contra idoso serão obrigatoriamente comunicados pelos profissionais de saúde a quaisquer dos seguintes órgãos:

I - autoridade policial;

II - Ministério Público;

III - Conselho Municipal do Idoso;

IV - Conselho Estadual do Idoso;

V - Conselho Nacional do Idoso.

\section{CAPÍTULO V}

Da Educação, Cultura, Esporte e Lazer

Art. 20. O idoso tem direito a educação, cultura, esporte, lazer, diversões, espetáculos, produtos e serviços que respeitem sua peculiar condição de idade.

Art. 21. O Poder Público criará oportunidades de acesso do idoso à educação, adequando currículos, metodologias e material didático aos programas educacionais a ele destinados.

$\S 1^{\circ}$ Os cursos especiais para idosos incluirão conteúdo relativo às técnicas de comunicação, computação e demais avanços tecnológicos, para sua integração à vida moderna.

$\S 2^{\circ}$ Os idosos participarão das comemorações de caráter cívico ou cultural, para transmissão de conhecimentos e vivências às demais gerações, no sentido da preservação da memória e da identidade culturais.

Art. 22. Nos currículos mínimos dos diversos níveis de ensino formal serão inseridos conteúdos voltados ao processo de envelhecimento, ao respeito e à 
valorização do idoso, de forma a eliminar o preconceito e a produzir conhecimentos sobre a matéria.

Art. 23. A participação dos idosos em atividades culturais e de lazer será proporcionada mediante descontos de pelo menos 50\% (cinqüenta por cento) nos ingressos para eventos artísticos, culturais, esportivos e de lazer, bem como o acesso preferencial aos respectivos locais.

Art. 24. Os meios de comunicação manterão espaços ou horários especiais voltados aos idosos, com finalidade informativa, educativa, artística e cultural, e ao público sobre o processo de envelhecimento.

Art. 25. O Poder Público apoiará a criação de universidade aberta para as pessoas idosas e incentivará a publicação de livros e periódicos, de conteúdo e padrão editorial adequados ao idoso, que facilitem a leitura, considerada a natural redução da capacidade visual.

\section{CAPÍTULO VI}

Da Profissionalização e do Trabalho

Art. 26. O idoso tem direito ao exercício de atividade profissional, respeitadas suas condições físicas, intelectuais e psíquicas.

Art. 27. Na admissão do idoso em qualquer trabalho ou emprego, é vedada a discriminação e a fixação de limite máximo de idade, inclusive para concursos, ressalvados os casos em que a natureza do cargo o exigir.

Parágrafo único. O primeiro critério de desempate em concurso público será a idade, dando-se preferência ao de idade mais elevada.

Art. 28. O Poder Público criará e estimulará programas de:

I - profissionalização especializada para os idosos, aproveitando seus potenciais e habilidades para atividades regulares e remuneradas;

II - preparação dos trabalhadores para a aposentadoria, com antecedência mínima de 1 (um) ano, por meio de estímulo a novos projetos sociais, conforme seus interesses, e de esclarecimento sobre os direitos sociais e de cidadania;

III - estímulo às empresas privadas para admissão de idosos ao trabalho.

\section{CAPÍTULO VII}

\section{Da Previdência Social}

Art. 29. Os benefícios de aposentadoria e pensão do Regime Geral da Previdência Social observarão, na sua concessão, critérios de cálculo que preservem o valor real dos salários sobre os quais incidiram contribuição, nos termos da legislação vigente. 
Parágrafo único. Os valores dos benefícios em manutenção serão reajustados na mesma data de reajuste do salário-mínimo, pro rata, de acordo com suas respectivas datas de início ou do seu último reajustamento, com base em percentual definido em regulamento, observados os critérios estabelecidos pela Lei $n^{\circ} 8.213$, de 24 de julho de 1991.

Art. 30. A perda da condição de segurado não será considerada para a concessão da aposentadoria por idade, desde que a pessoa conte com, no mínimo, o tempo de contribuição correspondente ao exigido para efeito de carência na data de requerimento do benefício.

Parágrafo único. O cálculo do valor do benefício previsto no caput observará o disposto no caput e $\S 2^{\circ}$ do art. $3^{\circ}$ da Lei $n^{\circ} 9.876$, de 26 de novembro de 1999, ou, não havendo salários-de-contribuição recolhidos a partir da competência de julho de 1994, o disposto no art. 35 da Lei nº 8.213, de 1991.

Art. 31. O pagamento de parcelas relativas a benefícios, efetuado com atraso por responsabilidade da Previdência Social, será atualizado pelo mesmo índice utilizado para os reajustamentos dos benefícios do Regime Geral de Previdência Social, verificado no período compreendido entre o mês que deveria ter sido pago e o mês do efetivo pagamento.

Art. 32. O Dia Mundial do Trabalho, $1^{\circ}$ de Maio, é a data-base dos aposentados e pensionistas.

\section{CAPÍTULO VIII}

\section{Da Assistência Social}

Art. 33. A assistência social aos idosos será prestada, de forma articulada, conforme os princípios e diretrizes previstos na Lei Orgânica da Assistência Social, na Política Nacional do Idoso, no Sistema Único de Saúde e demais normas pertinentes.

Art. 34. Aos idosos, a partir de 65 (sessenta e cinco) anos, que não possuam meios para prover sua subsistência, nem de tê-la provida por sua família, é assegurado o benefício mensal de 1 (um) salário-mínimo, nos termos da Lei Orgânica da Assistência Social - Loas.

Parágrafo único. O benefício já concedido a qualquer membro da família nos termos do caput não será computado para os fins do cálculo da renda familiar per capita a que se refere a Loas.

Art. 35. Todas as entidades de longa permanência, ou casa-lar, são obrigadas a firmar contrato de prestação de serviços com a pessoa idosa abrigada.

$\S 1^{\circ}$ No caso de entidades filantrópicas, ou casa-lar, é facultada a cobrança de participação do idoso no custeio da entidade. 
$\S 2^{\circ}$ O Conselho Municipal do Idoso ou o Conselho Municipal da Assistência Social estabelecerá a forma de participação prevista no $\S 1^{\circ}$, que não poderá exceder a $70 \%$ (setenta por cento) de qualquer benefício previdenciário ou de assistência social percebido pelo idoso.

$\S 3^{\circ}$ Se a pessoa idosa for incapaz, caberá a seu representante legal firmar o contrato a que se refere o caput deste artigo.

Art. 36. O acolhimento de idosos em situação de risco social, por adulto ou núcleo familiar, caracteriza a dependência econômica, para os efeitos legais.

\section{CAPÍTULO IX}

Da Habitação

Art. 37. O idoso tem direito a moradia digna, no seio da família natural ou substituta, ou desacompanhado de seus familiares, quando assim o desejar, ou, ainda, em instituição pública ou privada.

$\S 1^{\circ} \mathrm{A}$ assistência integral na modalidade de entidade de longa permanência será prestada quando verificada inexistência de grupo familiar, casa-lar, abandono ou carência de recursos financeiros próprios ou da família.

$\S 2^{\circ}$ Toda instituição dedicada ao atendimento ao idoso fica obrigada a manter identificação externa visível, sob pena de interdição, além de atender toda a legislação pertinente.

$\S 3^{\circ}$ As instituições que abrigarem idosos são obrigadas a manter padrões de habitação compatíveis com as necessidades deles, bem como provê-los com alimentação regular e higiene indispensáveis às normas sanitárias e com estas condizentes, sob as penas da lei.

Art. 38. Nos programas habitacionais, públicos ou subsidiados com recursos públicos, o idoso goza de prioridade na aquisição de imóvel para moradia própria, observado o seguinte: aos idosos;

I - reserva de $3 \%$ (três por cento) das unidades residenciais para atendimento

II - implantação de equipamentos urbanos comunitários voltados ao idoso;

III - eliminação de barreiras arquitetônicas e urbanísticas, para garantia de acessibilidade ao idoso;

IV - critérios de financiamento compatíveis com os rendimentos de aposentadoria e pensão.

CAPÍTULO X

Do Transporte 
Art. 39. Aos maiores de 65 (sessenta e cinco) anos fica assegurada a gratuidade dos transportes coletivos públicos urbanos e semi-urbanos, exceto nos serviços seletivos e especiais, quando prestados paralelamente aos serviços regulares.

$\S 1^{\circ}$ Para ter acesso à gratuidade, basta que o idoso apresente qualquer documento pessoal que faça prova de sua idade.

$\S 2^{\circ}$ Nos veículos de transporte coletivo de que trata este artigo, serão reservados $10 \%$ (dez por cento) dos assentos para os idosos, devidamente identificados com a placa de reservado preferencialmente para idosos.

$\S 3^{\circ}$ No caso das pessoas compreendidas na faixa etária entre 60 (sessenta) e 65 (sessenta e cinco) anos, ficará a critério da legislação local dispor sobre as condições para exercício da gratuidade nos meios de transporte previstos no caput deste artigo.

Art. 40. No sistema de transporte coletivo interestadual observar-se-á, nos termos da legislação específica: (Regulamento)

I - a reserva de 2 (duas) vagas gratuitas por veículo para idosos com renda igual ou inferior a 2 (dois) salários-mínimos;

II - desconto de 50\% (cinqüenta por cento), no mínimo, no valor das passagens, para os idosos que excederem as vagas gratuitas, com renda igual ou inferior a 2 (dois) salários-mínimos.

Parágrafo único. Caberá aos órgãos competentes definir os mecanismos e os critérios para o exercício dos direitos previstos nos incisos I e II.

Art. 41. É assegurada a reserva, para os idosos, nos termos da lei local, de 5\% (cinco por cento) das vagas nos estacionamentos públicos e privados, as quais deverão ser posicionadas de forma a garantir a melhor comodidade ao idoso.

Art. 42. É assegurada a prioridade do idoso no embarque no sistema de transporte coletivo.

TÍTULO III

Das Medidas de Proteção

CAPÍTULO I

Das Disposições Gerais

Art. 43. As medidas de proteção ao idoso são aplicáveis sempre que os direitos reconhecidos nesta Lei forem ameaçados ou violados:

I - por ação ou omissão da sociedade ou do Estado; 
II - por falta, omissão ou abuso da família, curador ou entidade de atendimento;

III - em razão de sua condição pessoal.

\section{CAPÍTULO II}

Das Medidas Específicas de Proteção

Art. 44. As medidas de proteção ao idoso previstas nesta Lei poderão ser aplicadas, isolada ou cumulativamente, e levarão em conta os fins sociais a que se destinam e o fortalecimento dos vínculos familiares e comunitários.

Art. 45. Verificada qualquer das hipóteses previstas no art. 43, o Ministério Público ou o Poder Judiciário, a requerimento daquele, poderá determinar, dentre outras, as seguintes medidas:

I - encaminhamento à família ou curador, mediante termo de responsabilidade;

II - orientação, apoio e acompanhamento temporários;

III - requisição para tratamento de sua saúde, em regime ambulatorial, hospitalar ou domiciliar;

IV - inclusão em programa oficial ou comunitário de auxílio, orientação e tratamento a usuários dependentes de drogas lícitas ou ilícitas, ao próprio idoso ou à pessoa de sua convivência que lhe cause perturbação;

V - abrigo em entidade;

$\mathrm{VI}$ - abrigo temporário.

TÍTULO IV

Da Política de Atendimento ao Idoso

CAPÍTULO I

Disposições Gerais

Art. 46. A política de atendimento ao idoso far-se-á por meio do conjunto articulado de ações governamentais e não-governamentais da União, dos Estados, do Distrito Federal e dos Municípios.

Art. 47. São linhas de ação da política de atendimento:

I - políticas sociais básicas, previstas na Lei ${ }^{\circ} 8.842$, de 4 de janeiro de 1994;

II - políticas e programas de assistência social, em caráter supletivo, para aqueles que necessitarem; 
III - serviços especiais de prevenção e atendimento às vítimas de negligência, maus-tratos, exploração, abuso, crueldade e opressão;

IV - serviço de identificação e localização de parentes ou responsáveis por idosos abandonados em hospitais e instituições de longa permanência;

V - proteção jurídico-social por entidades de defesa dos direitos dos idosos;

VI - mobilização da opinião pública no sentido da participação dos diversos segmentos da sociedade no atendimento do idoso.

\section{CAPÍTULO II}

Das Entidades de Atendimento ao Idoso

Art. 48. As entidades de atendimento são responsáveis pela manutenção das próprias unidades, observadas as normas de planejamento e execução emanadas do órgão competente da Política Nacional do Idoso, conforme a Lei $n^{\circ} 8.842$, de 1994.

Parágrafo único. As entidades governamentais e não-governamentais de assistência ao idoso ficam sujeitas à inscrição de seus programas, junto ao órgão competente da Vigilância Sanitária e Conselho Municipal da Pessoa Idosa, e em sua falta, junto ao Conselho Estadual ou Nacional da Pessoa Idosa, especificando os regimes de atendimento, observados os seguintes requisitos:

I - oferecer instalações físicas em condições adequadas de habitabilidade, higiene, salubridade e segurança;

II - apresentar objetivos estatutários e plano de trabalho compatíveis com os princípios desta Lei;

III - estar regularmente constituída;

IV - demonstrar a idoneidade de seus dirigentes.

Art. 49. As entidades que desenvolvam programas de institucionalização de longa permanência adotarão os seguintes princípios:

I - preservação dos vínculos familiares;

II - atendimento personalizado e em pequenos grupos;

III - manutenção do idoso na mesma instituição, salvo em caso de força maior;

IV - participação do idoso nas atividades comunitárias, de caráter interno e externo;

V - observância dos direitos e garantias dos idosos; 
VI - preservação da identidade do idoso e oferecimento de ambiente de respeito e dignidade.

Parágrafo único. O dirigente de instituição prestadora de atendimento ao idoso responderá civil e criminalmente pelos atos que praticar em detrimento do idoso, sem prejuízo das sanções administrativas.

Art. 50. Constituem obrigações das entidades de atendimento:

I - celebrar contrato escrito de prestação de serviço com o idoso, especificando o tipo de atendimento, as obrigações da entidade e prestações decorrentes do contrato, com os respectivos preços, se for o caso;

II - observar os direitos e as garantias de que são titulares os idosos;

III - fornecer vestuário adequado, se for pública, e alimentação suficiente;

IV - oferecer instalações físicas em condições adequadas de habitabilidade;

$\mathrm{V}$ - oferecer atendimento personalizado;

VI - diligenciar no sentido da preservação dos vínculos familiares;

VII - oferecer acomodações apropriadas para recebimento de visitas;

VIII - proporcionar cuidados à saúde, conforme a necessidade do idoso;

IX - promover atividades educacionais, esportivas, culturais e de lazer;

$\mathrm{X}$ - propiciar assistência religiosa àqueles que desejarem, de acordo com suas crenças;

$\mathrm{XI}$ - proceder a estudo social e pessoal de cada caso;

XII - comunicar à autoridade competente de saúde toda ocorrência de idoso portador de doenças infecto-contagiosas;

XIII - providenciar ou solicitar que o Ministério Público requisite os documentos necessários ao exercício da cidadania àqueles que não os tiverem, na forma da lei; idosos;

XIV - fornecer comprovante de depósito dos bens móveis que receberem dos

XV - manter arquivo de anotações onde constem data e circunstâncias do atendimento, nome do idoso, responsável, parentes, endereços, cidade, relação de seus pertences, bem como o valor de contribuições, e suas alterações, se houver, e demais dados que possibilitem sua identificação e a individualização do atendimento; 
XVI - comunicar ao Ministério Público, para as providências cabíveis, a situação de abandono moral ou material por parte dos familiares;

XVII - manter no quadro de pessoal profissionais com formação específica.

Art. 51. As instituições filantrópicas ou sem fins lucrativos prestadoras de serviço ao idoso terão direito à assistência judiciária gratuita.

\section{CAPÍTULO III}

Da Fiscalização das Entidades de Atendimento

Art. 52. As entidades governamentais e não-governamentais de atendimento ao idoso serão fiscalizadas pelos Conselhos do Idoso, Ministério Público, Vigilância Sanitária e outros previstos em lei.

Art. 53. $O$ art. $7^{\circ}$ da Lei $n^{\circ} 8.842$, de 1994, passa a vigorar com a seguinte redação:

"Art. $7^{\circ}$ Compete aos Conselhos de que trata o art. $6^{\circ}$ desta Lei a supervisão, o acompanhamento, a fiscalização e a avaliação da política nacional do idoso, no âmbito das respectivas instâncias político-administrativas." (NR)

Art. 54. Será dada publicidade das prestações de contas dos recursos públicos e privados recebidos pelas entidades de atendimento.

Art. 55. As entidades de atendimento que descumprirem as determinações desta Lei ficarão sujeitas, sem prejuízo da responsabilidade civil e criminal de seus dirigentes ou prepostos, às seguintes penalidades, observado o devido processo legal:

I - as entidades governamentais:

a) advertência;

b) afastamento provisório de seus dirigentes;

c) afastamento definitivo de seus dirigentes;

d) fechamento de unidade ou interdição de programa;

II - as entidades não-governamentais:

a) advertência;

b) multa;

c) suspensão parcial ou total do repasse de verbas públicas;

d) interdição de unidade ou suspensão de programa; 
e) proibição de atendimento a idosos a bem do interesse público.

$\S 1^{\circ}$ Havendo danos aos idosos abrigados ou qualquer tipo de fraude em relação ao programa, caberá o afastamento provisório dos dirigentes ou a interdição da unidade e a suspensão do programa.

$\S 2^{\circ} \mathrm{A}$ suspensão parcial ou total do repasse de verbas públicas ocorrerá quando verificada a má aplicação ou desvio de finalidade dos recursos.

$\S 3^{\circ} \mathrm{Na}$ ocorrência de infração por entidade de atendimento, que coloque em risco os direitos assegurados nesta Lei, será o fato comunicado ao Ministério Público, para as providências cabíveis, inclusive para promover a suspensão das atividades ou dissolução da entidade, com a proibição de atendimento a idosos a bem do interesse público, sem prejuízo das providências a serem tomadas pela Vigilância Sanitária.

$\S 4^{\circ} \mathrm{Na}$ aplicação das penalidades, serão consideradas a natureza e a gravidade da infração cometida, os danos que dela provierem para o idoso, as circunstâncias agravantes ou atenuantes e os antecedentes da entidade.

CAPÍTULO IV

Das Infrações Administrativas

Art. 56. Deixar a entidade de atendimento de cumprir as determinações do art. 50 desta Lei:

Pena - multa de $R \$ 500,00$ (quinhentos reais) a $R \$ 3.000,00$ (três mil reais), se o fato não for caracterizado como crime, podendo haver a interdição do estabelecimento até que sejam cumpridas as exigências legais.

Parágrafo único. No caso de interdição do estabelecimento de longa permanência, os idosos abrigados serão transferidos para outra instituição, a expensas do estabelecimento interditado, enquanto durar a interdição.

Art. 57. Deixar o profissional de saúde ou o responsável por estabelecimento de saúde ou instituição de longa permanência de comunicar à autoridade competente os casos de crimes contra idoso de que tiver conhecimento:

Pena - multa de $R \$ 500,00$ (quinhentos reais) a $R \$ 3.000,00$ (três mil reais), aplicada em dobro no caso de reincidência.

Art. 58. Deixar de cumprir as determinações desta Lei sobre a prioridade no atendimento ao idoso:

Pena - multa de $R \$ 500,00$ (quinhentos reais) a $R \$ 1.000,00$ (um mil reais) e multa civil a ser estipulada pelo juiz, conforme o dano sofrido pelo idoso. 
Da Apuração Administrativa de Infração às

Normas de Proteção ao Idoso

Art. 59. Os valores monetários expressos no Capítulo IV serão atualizados anualmente, na forma da lei.

Art. 60. O procedimento para a imposição de penalidade administrativa por infração às normas de proteção ao idoso terá início com requisição do Ministério Público ou auto de infração elaborado por servidor efetivo e assinado, se possível, por duas testemunhas.

$\S 1^{\circ}$ No procedimento iniciado com o auto de infração poderão ser usadas fórmulas impressas, especificando-se a natureza e as circunstâncias da infração.

$\S 2^{\circ}$ Sempre que possível, à verificação da infração seguir-se-á a lavratura do auto, ou este será lavrado dentro de 24 (vinte e quatro) horas, por motivo justificado.

Art. 61. O autuado terá prazo de 10 (dez) dias para a apresentação da defesa, contado da data da intimação, que será feita:

I - pelo autuante, no instrumento de autuação, quando for lavrado na presença do infrator;

II - por via postal, com aviso de recebimento.

Art. 62. Havendo risco para a vida ou à saúde do idoso, a autoridade competente aplicará à entidade de atendimento as sanções regulamentares, sem prejuízo da iniciativa e das providências que vierem a ser adotadas pelo Ministério Público ou pelas demais instituições legitimadas para a fiscalização.

Art. 63. Nos casos em que não houver risco para a vida ou a saúde da pessoa idosa abrigada, a autoridade competente aplicará à entidade de atendimento as sanções regulamentares, sem prejuízo da iniciativa e das providências que vierem a ser adotadas pelo Ministério Público ou pelas demais instituições legitimadas para a fiscalização.

\section{CAPÍTULO VI}

Da Apuração Judicial de Irregularidades em Entidade de Atendimento

Art. 64. Aplicam-se, subsidiariamente, ao procedimento administrativo de que trata este Capítulo as disposições das Leis $n^{\text {os }} 6.437$, de 20 de agosto de 1977, e 9.784, de 29 de janeiro de 1999.

Art. 65. O procedimento de apuração de irregularidade em entidade governamental e não-governamental de atendimento ao idoso terá início mediante petição fundamentada de pessoa interessada ou iniciativa do Ministério Público. 
Art. 66. Havendo motivo grave, poderá a autoridade judiciária, ouvido o Ministério Público, decretar liminarmente o afastamento provisório do dirigente da entidade ou outras medidas que julgar adequadas, para evitar lesão aos direitos do idoso, mediante decisão fundamentada.

Art. 67. O dirigente da entidade será citado para, no prazo de 10 (dez) dias, oferecer resposta escrita, podendo juntar documentos e indicar as provas a produzir.

Art. 68. Apresentada a defesa, o juiz procederá na conformidade do art. 69 ou, se necessário, designará audiência de instrução e julgamento, deliberando sobre a necessidade de produção de outras provas.

$\S 1^{\circ}$ Salvo manifestação em audiência, as partes e o Ministério Público terão 5 (cinco) dias para oferecer alegações finais, decidindo a autoridade judiciária em igual prazo.

$\S 2^{\circ} \mathrm{Em}$ se tratando de afastamento provisório ou definitivo de dirigente de entidade governamental, a autoridade judiciária oficiará a autoridade administrativa imediatamente superior ao afastado, fixando-lhe prazo de 24 (vinte e quatro) horas para proceder à substituição.

$\S 3^{\circ}$ Antes de aplicar qualquer das medidas, a autoridade judiciária poderá fixar prazo para a remoção das irregularidades verificadas. Satisfeitas as exigências, o processo será extinto, sem julgamento do mérito.

$\S 4^{\circ}$ A multa e a advertência serão impostas ao dirigente da entidade ou ao responsável pelo programa de atendimento.

\section{TÍTULO V}

Do Acesso à Justiça

\section{CAPÍTULO I}

\section{Disposições Gerais}

Art. 69. Aplica-se, subsidiariamente, às disposições deste Capítulo, o procedimento sumário previsto no Código de Processo Civil, naquilo que não contrarie os prazos previstos nesta Lei. idoso.

Art. 70. O Poder Público poderá criar varas especializadas e exclusivas do

Art. 71. É assegurada prioridade na tramitação dos processos e procedimentos e na execução dos atos e diligências judiciais em que figure como parte ou interveniente pessoa com idade igual ou superior a 60 (sessenta) anos, em qualquer instância.

$\S 1^{\circ} \mathrm{O}$ interessado na obtenção da prioridade a que alude este artigo, fazendo prova de sua idade, requererá o benefício à autoridade judiciária competente para 
decidir o feito, que determinará as providências a serem cumpridas, anotando-se essa circunstância em local visível nos autos do processo.

$\S 2^{\circ}$ A prioridade não cessará com a morte do beneficiado, estendendo-se em favor do cônjuge supérstite, companheiro ou companheira, com união estável, maior de 60 (sessenta) anos.

$\S 3^{\circ} \mathrm{A}$ prioridade se estende aos processos e procedimentos na Administração Pública, empresas prestadoras de serviços públicos e instituições financeiras, ao atendimento preferencial junto à Defensoria Publica da União, dos Estados e do Distrito Federal em relação aos Serviços de Assistência Judiciária.

$\S 4^{\circ}$ Para o atendimento prioritário será garantido ao idoso o fácil acesso aos assentos e caixas, identificados com a destinação a idosos em local visível e caracteres legíveis.

\section{CAPÍTULO II}

Do Ministério Público

\section{Art. 72. (VETADO)}

Art. 73. As funções do Ministério Público, previstas nesta Lei, serão exercidas nos termos da respectiva Lei Orgânica.

Art. 74. Compete ao Ministério Público:

I - instaurar o inquérito civil e a ação civil pública para a proteção dos direitos e interesses difusos ou coletivos, individuais indisponíveis e individuais homogêneos do idoso;

II - promover e acompanhar as ações de alimentos, de interdição total ou parcial, de designação de curador especial, em circunstâncias que justifiquem a medida e oficiar em todos os feitos em que se discutam os direitos de idosos em condições de risco;

III - atuar como substituto processual do idoso em situação de risco, conforme o disposto no art. 43 desta Lei;

IV - promover a revogação de instrumento procuratório do idoso, nas hipóteses previstas no art. 43 desta Lei, quando necessário ou o interesse público justificar;

V - instaurar procedimento administrativo e, para instruí-lo:

a) expedir notificações, colher depoimentos ou esclarecimentos e, em caso de não comparecimento injustificado da pessoa notificada, requisitar condução coercitiva, inclusive pela Polícia Civil ou Militar; 
b) requisitar informações, exames, perícias e documentos de autoridades municipais, estaduais e federais, da administração direta e indireta, bem como promover inspeções e diligências investigatórias;

c) requisitar informações e documentos particulares de instituições privadas;

VI - instaurar sindicâncias, requisitar diligências investigatórias e a instauração de inquérito policial, para a apuração de ilícitos ou infrações às normas de proteção ao idoso;

VII - zelar pelo efetivo respeito aos direitos e garantias legais assegurados ao idoso, promovendo as medidas judiciais e extrajudiciais cabíveis;

VIII - inspecionar as entidades públicas e particulares de atendimento e os programas de que trata esta Lei, adotando de pronto as medidas administrativas ou judiciais necessárias à remoção de irregularidades porventura verificadas;

IX - requisitar força policial, bem como a colaboração dos serviços de saúde, educacionais e de assistência social, públicos, para o desempenho de suas atribuições;

$X$ - referendar transações envolvendo interesses e direitos dos idosos previstos nesta Lei.

$\S 1^{\circ} \mathrm{A}$ legitimação do Ministério Público para as ações cíveis previstas neste artigo não impede a de terceiros, nas mesmas hipóteses, segundo dispuser a lei.

$\S 2^{\circ}$ As atribuições constantes deste artigo não excluem outras, desde que compatíveis com a finalidade e atribuições do Ministério Público.

$\S 3^{\circ} \mathrm{O}$ representante do Ministério Público, no exercício de suas funções, terá livre acesso a toda entidade de atendimento ao idoso.

Art. 75. Nos processos e procedimentos em que não for parte, atuará obrigatoriamente o Ministério Público na defesa dos direitos e interesses de que cuida esta Lei, hipóteses em que terá vista dos autos depois das partes, podendo juntar documentos, requerer diligências e produção de outras provas, usando os recursos cabíveis.

Art. 76. A intimação do Ministério Público, em qualquer caso, será feita pessoalmente.

Art. 77. A falta de intervenção do Ministério Público acarreta a nulidade do feito, que será declarada de ofício pelo juiz ou a requerimento de qualquer interessado.

CAPÍTULO III

Da Proteção Judicial dos Interesses Difusos, Coletivos e Individuais Indisponíveis ou Homogêneos 
Art. 78. As manifestações processuais do representante do Ministério Público deverão ser fundamentadas.

Art. 79. Regem-se pelas disposições desta Lei as ações de responsabilidade por ofensa aos direitos assegurados ao idoso, referentes à omissão ou ao oferecimento insatisfatório de:

I - acesso às ações e serviços de saúde;

II - atendimento especializado ao idoso portador de deficiência ou com limitação incapacitante;

III - atendimento especializado ao idoso portador de doença infecto-contagiosa;

IV - serviço de assistência social visando ao amparo do idoso.

Parágrafo único. As hipóteses previstas neste artigo não excluem da proteção judicial outros interesses difusos, coletivos, individuais indisponíveis ou homogêneos, próprios do idoso, protegidos em lei.

Art. 80. As ações previstas neste Capítulo serão propostas no foro do domicílio do idoso, cujo juízo terá competência absoluta para processar a causa, ressalvadas as competências da Justiça Federal e a competência originária dos Tribunais Superiores.

Art. 81. Para as ações cíveis fundadas em interesses difusos, coletivos, individuais indisponíveis ou homogêneos, consideram-se legitimados, concorrentemente:

I - o Ministério Público;

II - a União, os Estados, o Distrito Federal e os Municípios;

III - a Ordem dos Advogados do Brasil;

IV - as associações legalmente constituídas há pelo menos 1 (um) ano e que incluam entre os fins institucionais a defesa dos interesses e direitos da pessoa idosa, dispensada a autorização da assembléia, se houver prévia autorização estatutária.

$\S 1^{\circ}$ Admitir-se-á litisconsórcio facultativo entre os Ministérios Públicos da União e dos Estados na defesa dos interesses e direitos de que cuida esta Lei.

$\S 2^{\circ} \mathrm{Em}$ caso de desistência ou abandono da ação por associação legitimada, o Ministério Público ou outro legitimado deverá assumir a titularidade ativa.

Art. 82. Para defesa dos interesses e direitos protegidos por esta Lei, são admissíveis todas as espécies de ação pertinentes. 
Parágrafo único. Contra atos ilegais ou abusivos de autoridade pública ou agente de pessoa jurídica no exercício de atribuições de Poder Público, que lesem direito líquido e certo previsto nesta Lei, caberá ação mandamental, que se regerá pelas normas da lei do mandado de segurança.

Art. 83. Na ação que tenha por objeto o cumprimento de obrigação de fazer ou não-fazer, o juiz concederá a tutela específica da obrigação ou determinará providências que assegurem o resultado prático equivalente ao adimplemento.

$\S 1^{\circ}$ Sendo relevante o fundamento da demanda e havendo justificado receio de ineficácia do provimento final, é lícito ao juiz conceder a tutela liminarmente ou após justificação prévia, na forma do art. 273 do Código de Processo Civil.

$\S 2^{\circ} \mathrm{O}$ juiz poderá, na hipótese do $\S 1^{\circ}$ ou na sentença, impor multa diária ao réu, independentemente do pedido do autor, se for suficiente ou compatível com a obrigação, fixando prazo razoável para o cumprimento do preceito.

$\S 3^{\circ} \mathrm{A}$ multa só será exigível do réu após o trânsito em julgado da sentença favorável ao autor, mas será devida desde o dia em que se houver configurado.

Art. 84. Os valores das multas previstas nesta Lei reverterão ao Fundo do Idoso, onde houver, ou na falta deste, ao Fundo Municipal de Assistência Social, ficando vinculados ao atendimento ao idoso.

Parágrafo único. As multas não recolhidas até 30 (trinta) dias após o trânsito em julgado da decisão serão exigidas por meio de execução promovida pelo Ministério Público, nos mesmos autos, facultada igual iniciativa aos demais legitimados em caso de inércia daquele.

Art. 85. O juiz poderá conferir efeito suspensivo aos recursos, para evitar dano irreparável à parte.

Art. 86. Transitada em julgado a sentença que impuser condenação ao Poder Público, o juiz determinará a remessa de peças à autoridade competente, para apuração da responsabilidade civil e administrativa do agente a que se atribua a ação ou omissão.

Art. 87. Decorridos 60 (sessenta) dias do trânsito em julgado da sentença condenatória favorável ao idoso sem que o autor lhe promova a execução, deverá fazê-lo o Ministério Público, facultada, igual iniciativa aos demais legitimados, como assistentes ou assumindo o pólo ativo, em caso de inércia desse órgão.

Art. 88. Nas ações de que trata este Capítulo, não haverá adiantamento de custas, emolumentos, honorários periciais e quaisquer outras despesas.

Parágrafo único. Não se imporá sucumbência ao Ministério Público.

Art. 89. Qualquer pessoa poderá, e o servidor deverá, provocar a iniciativa do Ministério Público, prestando-lhe informações sobre os fatos que constituam objeto de ação civil e indicando-lhe os elementos de convicção. 
Art. 90. Os agentes públicos em geral, os juízes e tribunais, no exercício de suas funções, quando tiverem conhecimento de fatos que possam configurar crime de ação pública contra idoso ou ensejar a propositura de ação para sua defesa, devem encaminhar as peças pertinentes ao Ministério Público, para as providências cabíveis.

Art. 91. Para instruir a petição inicial, o interessado poderá requerer às autoridades competentes as certidões e informações que julgar necessárias, que serão fornecidas no prazo de 10 (dez) dias.

Art. 92. O Ministério Público poderá instaurar sob sua presidência, inquérito civil, ou requisitar, de qualquer pessoa, organismo público ou particular, certidões, informações, exames ou perícias, no prazo que assinalar, o qual não poderá ser inferior a 10 (dez) dias.

$\S 1^{\circ}$ Se o órgão do Ministério Público, esgotadas todas as diligências, se convencer da inexistência de fundamento para a propositura da ação civil ou de peças informativas, determinará 0 seu arquivamento, fazendo-o fundamentadamente.

$\S 2^{\circ}$ Os autos do inquérito civil ou as peças de informação arquivados serão remetidos, sob pena de se incorrer em falta grave, no prazo de 3 (três) dias, ao Conselho Superior do Ministério Público ou à Câmara de Coordenação e Revisão do Ministério Público.

$\S 3^{\circ}$ Até que seja homologado ou rejeitado o arquivamento, pelo Conselho Superior do Ministério Público ou por Câmara de Coordenação e Revisão do Ministério Público, as associações legitimadas poderão apresentar razões escritas ou documentos, que serão juntados ou anexados às peças de informação.

$\S 4^{\circ}$ Deixando o Conselho Superior ou a Câmara de Coordenação e Revisão do Ministério Público de homologar a promoção de arquivamento, será designado outro membro do Ministério Público para o ajuizamento da ação.

TÍTULO VI

Dos Crimes

CAPÍTULO I

Disposições Gerais

Art. 93. Aplicam-se subsidiariamente, no que couber, as disposições da Lei $\mathrm{n}^{\circ}$ 7.347, de 24 de julho de 1985.

Art. 94. Aos crimes previstos nesta Lei, cuja pena máxima privativa de liberdade não ultrapasse 4 (quatro) anos, aplica-se o procedimento previsto na Lei $n^{\circ} 9.099$, de 26 de setembro de 1995, e, subsidiariamente, no que couber, as disposições do Código Penal e do Código de Processo Penal. 


\section{CAPÍTULO II}

\section{Dos Crimes em Espécie}

Art. 95. Os crimes definidos nesta Lei são de ação penal pública incondicionada, não se lhes aplicando os arts. 181 e 182 do Código Penal.

Art. 96. Discriminar pessoa idosa, impedindo ou dificultando seu acesso a operações bancárias, aos meios de transporte, ao direito de contratar ou por qualquer outro meio ou instrumento necessário ao exercício da cidadania, por motivo de idade:

Pena - reclusão de 6 (seis) meses a 1 (um) ano e multa.

$\S 1^{\circ} \mathrm{Na}$ mesma pena incorre quem desdenhar, humilhar, menosprezar ou discriminar pessoa idosa, por qualquer motivo.

$\S 2^{\circ}$ A pena será aumentada de $1 / 3$ (um terço) se a vítima se encontrar sob os cuidados ou responsabilidade do agente.

Art. 97. Deixar de prestar assistência ao idoso, quando possível fazê-lo sem risco pessoal, em situação de iminente perigo, ou recusar, retardar ou dificultar sua assistência à saúde, sem justa causa, ou não pedir, nesses casos, o socorro de autoridade pública:

Pena - detenção de 6 (seis) meses a 1 (um) ano e multa.

Parágrafo único. A pena é aumentada de metade, se da omissão resulta lesão corporal de natureza grave, e triplicada, se resulta a morte.

Art. 98. Abandonar o idoso em hospitais, casas de saúde, entidades de longa permanência, ou congêneres, ou não prover suas necessidades básicas, quando obrigado por lei ou mandado:

Pena - detenção de 6 (seis) meses a 3 (três) anos e multa.

Art. 99. Expor a perigo a integridade e a saúde, física ou psíquica, do idoso, submetendo-o a condições desumanas ou degradantes ou privando-o de alimentos e cuidados indispensáveis, quando obrigado a fazê-lo, ou sujeitando-o a trabalho excessivo ou inadequado:

Pena - detenção de 2 (dois) meses a 1 (um) ano e multa.

$\S 1^{\circ}$ Se do fato resulta lesão corporal de natureza grave:

Pena - reclusão de 1 (um) a 4 (quatro) anos.

$\S 2^{\circ}$ Se resulta a morte:

Pena - reclusão de 4 (quatro) a 12 (doze) anos. 

multa:

Art. 100. Constitui crime punível com reclusão de 6 (seis) meses a 1 (um) ano e

I - obstar o acesso de alguém a qualquer cargo público por motivo de idade;

II - negar a alguém, por motivo de idade, emprego ou trabalho;

III - recusar, retardar ou dificultar atendimento ou deixar de prestar assistência à saúde, sem justa causa, a pessoa idosa;

IV - deixar de cumprir, retardar ou frustrar, sem justo motivo, a execução de ordem judicial expedida na ação civil a que alude esta Lei;

$\mathrm{V}$ - recusar, retardar ou omitir dados técnicos indispensáveis à propositura da ação civil objeto desta Lei, quando requisitados pelo Ministério Público.

Art. 101. Deixar de cumprir, retardar ou frustrar, sem justo motivo, a execução de ordem judicial expedida nas ações em que for parte ou interveniente o idoso:

Pena - detenção de 6 (seis) meses a 1 (um) ano e multa.

Art. 102. Apropriar-se de ou desviar bens, proventos, pensão ou qualquer outro rendimento do idoso, dando-Ihes aplicação diversa da de sua finalidade:

Pena - reclusão de 1 (um) a 4 (quatro) anos e multa.

Art. 103. Negar o acolhimento ou a permanência do idoso, como abrigado, por recusa deste em outorgar procuração à entidade de atendimento:

Pena - detenção de 6 (seis) meses a 1 (um) ano e multa.

Art. 104. Reter o cartão magnético de conta bancária relativa a benefícios, proventos ou pensão do idoso, bem como qualquer outro documento com objetivo de assegurar recebimento ou ressarcimento de dívida:

Pena - detenção de 6 (seis) meses a 2 (dois) anos e multa.

Art. 105. Exibir ou veicular, por qualquer meio de comunicação, informações ou imagens depreciativas ou injuriosas à pessoa do idoso:

Pena - detenção de 1 (um) a 3 (três) anos e multa.

Art. 106. Induzir pessoa idosa sem discernimento de seus atos a outorgar procuração para fins de administração de bens ou deles dispor livremente:

Pena - reclusão de 2 (dois) a 4 (quatro) anos.

Art. 107. Coagir, de qualquer modo, o idoso a doar, contratar, testar ou outorgar procuração: 
Pena - reclusão de 2 (dois) a 5 (cinco) anos.

Art. 108. Lavrar ato notarial que envolva pessoa idosa sem discernimento de seus atos, sem a devida representação legal:

Pena - reclusão de 2 (dois) a 4 (quatro) anos.

TÍTULO VII

Disposições Finais e Transitórias

Art. 109. Impedir ou embaraçar ato do representante do Ministério Público ou de qualquer outro agente fiscalizador:

Pena - reclusão de 6 (seis) meses a 1 (um) ano e multa.

Art. 110. O Decreto-Lei $\mathrm{n}^{\circ}$ 2.848, de 7 de dezembro de 1940, Código Penal, passa a vigorar com as seguintes alterações:

"Art. 61.

II -

h) contra criança, maior de 60 (sessenta) anos, enfermo ou mulher grávida; " (NR)

"Art. 121.

$\S 4^{\circ}$ No homicídio culposo, a pena é aumentada de $1 / 3$ (um terço), se o crime resulta de inobservância de regra técnica de profissão, arte ou ofício, ou se o agente deixa de prestar imediato socorro à vítima, não procura diminuir as conseqüências do seu ato, ou foge para evitar prisão em flagrante. Sendo doloso o homicídio, a pena é aumentada de $1 / 3$ (um terço) se o crime é praticado contra pessoa menor de 14 (quatorze) ou maior de 60 (sessenta) anos.

"Art. 133. 
III - se a vítima é maior de 60 (sessenta) anos." (NR)

"Art. 140.

$\S 3^{\circ}$ Se a injúria consiste na utilização de elementos referentes a raça, cor, etnia, religião, origem ou a condição de pessoa idosa ou portadora de deficiência:

$(\mathrm{NR})$

"Art. 141.

IV - contra pessoa maior de 60 (sessenta) anos ou portadora de deficiência, exceto no caso de injúria.

" (NR)

"Art. 148.

$\S 1^{\circ}$

I - se a vítima é ascendente, descendente, cônjuge do agente ou maior de 60 (sessenta) anos.

." (NR)

"Art. 159

$\S 1^{\circ}$ Se o seqüestro dura mais de 24 (vinte e quatro) horas, se o seqüestrado é menor de 18 (dezoito) ou maior de 60 (sessenta) anos, ou se o crime é cometido por bando ou quadrilha.

" (NR)

"Art. 183

III - se o crime é praticado contra pessoa com idade igual ou superior a 60 (sessenta) anos." (NR) 
"Art. 244. Deixar, sem justa causa, de prover a subsistência do cônjuge, ou de filho menor de 18 (dezoito) anos ou inapto para o trabalho, ou de ascendente inválido ou maior de 60 (sessenta) anos, não lhes proporcionando os recursos necessários ou faltando ao pagamento de pensão alimentícia judicialmente acordada, fixada ou majorada; deixar, sem justa causa, de socorrer descendente ou ascendente, gravemente enfermo:

Art. 111. O O art. 21 do Decreto-Lei $n^{\circ} 3.688$, de 3 de outubro de 1941, Lei das Contravenções Penais, passa a vigorar acrescido do seguinte parágrafo único:

"Art. 21

Parágrafo único. Aumenta-se a pena de 1/3 (um terço) até a metade se a vítima é maior de 60 (sessenta) anos." (NR)

Art. 112. O inciso II do $\S 4^{\circ}$ do art. $1^{\circ}$ da Lei $n^{\circ} 9.455$, de 7 de abril de 1997, passa a vigorar com a seguinte redação:

"Art. $1^{\circ}$

$\S 4^{\circ}$

II - se o crime é cometido contra criança, gestante, portador de deficiência, adolescente ou maior de 60 (sessenta) anos;

Art. 113. O inciso III do art. 18 da Lei $n^{\circ} 6.368$, de 21 de outubro de 1976, passa a vigorar com a seguinte redação:

"Art. 18

III - se qualquer deles decorrer de associação ou visar a menores de 21 (vinte e um) anos ou a pessoa com idade igual ou superior a 60 (sessenta) anos ou a quem tenha, por qualquer causa, diminuída ou suprimida a capacidade de discernimento ou de autodeterminação:

." (NR)

Art. 114. $O$ art $1^{\circ}$ da Lei $n^{\circ} 10.048$, de 8 de novembro de 2000 , passa a vigorar com a seguinte redação: 
"Art. $1^{\circ}$ As pessoas portadoras de deficiência, os idosos com idade igual ou superior a 60 (sessenta) anos, as gestantes, as lactantes e as pessoas acompanhadas por crianças de colo terão atendimento prioritário, nos termos desta Lei." (NR)

Art. 115. O Orçamento da Seguridade Social destinará ao Fundo Nacional de Assistência Social, até que o Fundo Nacional do Idoso seja criado, os recursos necessários, em cada exercício financeiro, para aplicação em programas e ações relativos ao idoso.

Art. 116. Serão incluídos nos censos demográficos dados relativos à população idosa do País.

Art. 117. O Poder Executivo encaminhará ao Congresso Nacional projeto de lei revendo os critérios de concessão do Benefício de Prestação Continuada previsto na Lei Orgânica da Assistência Social, de forma a garantir que o acesso ao direito seja condizente com o estágio de desenvolvimento sócio-econômico alcançado pelo País.

Art. 118. Esta Lei entra em vigor decorridos 90 (noventa) dias da sua publicação, ressalvado o disposto no caput do art. 36 , que vigorará a partir de $1^{\circ}$ de janeiro de 2004.

Brasília, $1^{\circ}$ de outubro de $2003 ; 182^{\circ}$ da Independência e $115^{\circ}$ da República.

LUIZ INÁCIO LULA DA SILVA

Márcio Thomaz Bastos

Antonio Palocci Filho

Rubem Fonseca Filho

Humberto Sérgio Costa LIma

Guido Mantega

Ricardo José Ribeiro Berzoini

Benedita Souza da Silva Sampaio

Álvaro Augusto Ribeiro Costa

Este texto não substitui o publicado no D.O.U. de 3.10.2003 